\title{
United States Army Officer Personnel Reforms and the Decline of Rank Flexibility, 1890s-1920s
}

\author{
A Monograph \\ by \\ MAJ Daniel P. Snow \\ United States Army

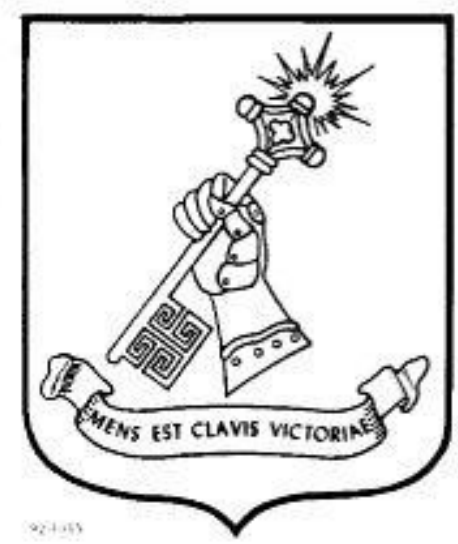 \\ School of Advanced Military Studies \\ United States Army Command and General Staff College \\ Fort Leavenworth, Kansas \\ 2014-02
}




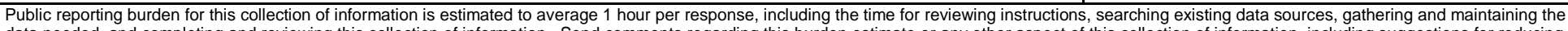

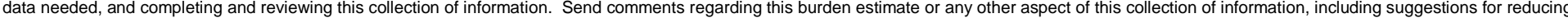

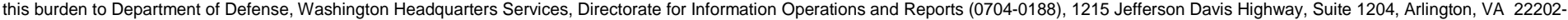

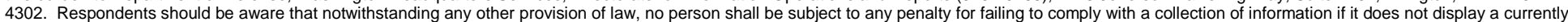
valid OMB control number. PLEASE DO NOT RETURN YOUR FORM TO THE ABOVE ADDRESS.

\begin{tabular}{l|l|l} 
1. REPORT DATE (DD-MM-YYYY) & 2. REPORT TYPE & 3. DATES COVERED (FrOm - To)
\end{tabular}

04-12-2014 $\quad$ SAMS Monograph

\section{TITLE AND SUBTITLE}

United States Army Officer Personnel Reforms and the Decline of Rank Flexibility, 1890s1920s

FEBRUARY 2014 - DECEMBER 2014

5a. CONTRACT NUMBER

5b. GRANT NUMBER

5c. PROGRAM ELEMENT NUMBER

6. AUTHOR(S)

MAJ Daniel P. Snow, United States Army

5d. PROJECT NUMBER

5e. TASK NUMBER

5f. WORK UNIT NUMBER

7. PERFORMING ORGANIZATION NAME(S) AND ADDRESS(ES)

School of Advanced Military Studies (SAMS)

8. PERFORMING ORGANIZATION REPORT

201 Reynolds Avenue

Fort Leavenworth, KS 66027-2134 NUMBER

9. SPONSORING I MONITORING AGENCY NAME(S) AND ADDRESS(ES)

Command and General Staff College

731 McClellan Avenue

Fort Leavenworth, KS 66027-1350

CGSC

11. SPONSOR/MONITOR'S REPORT NUMBER(S)

\section{DISTRIBUTION I AVAILABILITY STATEMENT}

Approved for Public Release; Distribution Unlimited

\section{SUPPLEMENTARY NOTES}

\section{ABSTRACT}

The contemporary United States Army officer corps is the legacy of progressive era reforms that discarded the decentralized and personal system of managing talent in favor of a centralized system based on scientific organization and efficiency. At the turn of the twentieth century, in response to institutional, cultural, and strategic conditions, the Army underwent a transition in the way it administered its officers, fundamentally transforming the emphasis of it officer management. Structurally, the Army went from a traditional decentralized and intimate activity built on individual effectiveness into centralized, industrial process in the pursuit of optimizing organizational efficiency. Influenced by a "managerial revolution" and progressive thought, Army advocates for change at all levels sought professionalization reforms based in the managerial and organizational skills of its officers rather than trust in loosely defined heroism and military genius. Progressive-inspired reforms allowed the institution to adapt for the new era of industrial war. The Army designed its professional Army officer of the twentieth century to reflect predictability, standardization, order, and efficiency. This analysis focuses on the history of the early reforms in order to grasp the fundamental shift in the focus of officer talent management and explain the origin of the modern personnel system. Rather than aggregating individual causes looking for the principal reason for change, this paper examines the individual, institutional, cultural, and contextual factors present at many levels in order to link and bind actions and decisions that collectively generated a refocused officer system. An appreciation of the way the military organization functioned before and after the transition allows for a better understanding for those who still experience it, study it, and try to explain it. A retrospective understanding of the officer talent management crisis the Army confronted at the turn of the century provides a perspective that mav prove useful to those interested in shaping the modern Armv for its future.

15. SUBJECT TERMS

\section{SECURITY CLASSIFICATION OF:}

a. REPORT

Unclassified

\section{b. ABSTRACT} Unclassified

\section{LIMITATION} OF ABSTRACT

\section{NUMBER OF PAGES}

62 19a. NAME OF RESPONSIBLE PERSON

19b. TELEPHONE NUMBER (include area code)

913-758-3302 


\section{MONOGRAPH APPROVAL PAGE}

Name of Candidate: MAJ Daniel P. Snow

Monograph Title: $\quad$ United States Army Officer Personnel Reforms and the Decline of Rank Flexibility, 1890s-1920s

Approved by:

Thomas A. Bruscino, PhD

, Monograph Director

, Seminar Leader

Andrew Morgado, LTC

, Director, School of Advanced Military Studies

Henry A. Arnold III, COL

Accepted this 4th day of December 2014 by:

Robert F. Baumann, PhD

, Director, Graduate Degree Programs

The opinions and conclusions expressed herein are those of the student author and do not necessarily represent the views of the US Army Command and General Staff College or any other governmental agency. (References to this study should include the foregoing statement.) 


\begin{abstract}
United States Army Officer Personnel Reforms and the Decline of Rank Flexibility, 1890s-1920s, by MAJ Daniel P. Snow, 62 pages.

The contemporary United States Army officer corps is the legacy of progressive era reforms that discarded the decentralized and personal system of managing talent in favor of a centralized system based on scientific organization and efficiency.

At the turn of the twentieth century, in response to institutional, cultural, and strategic conditions, the Army underwent a transition in the way it administered its officers, fundamentally transforming the emphasis of it officer management. Structurally, the Army went from a traditional decentralized and intimate activity built on individual effectiveness into centralized, industrial process in the pursuit of optimizing organizational efficiency. Influenced by a "managerial revolution" and progressive thought, Army advocates for change at all levels sought professionalization reforms based in the managerial and organizational skills of its officers rather than trust in loosely defined heroism and military genius. Progressive-inspired reforms allowed the institution to adapt for the new era of industrial war. The Army designed its professional Army officer of the twentieth century to reflect predictability, standardization, order, and efficiency.
\end{abstract}

This analysis focuses on the history of the early reforms in order to grasp the fundamental shift in the focus of officer talent management and explain the origin of the modern personnel system. Rather than aggregating individual causes looking for the principal reason for change, this paper examines the individual, institutional, cultural, and contextual factors present at many levels in order to link and bind actions and decisions that collectively generated a refocused officer system. An appreciation of the way the military organization functioned before and after the transition allows for a better understanding for those who still experience it, study it, and try to explain it. A retrospective understanding of the officer talent management crisis the Army confronted at the turn of the century provides a perspective that may prove useful to those interested in shaping the modern Army for its future. 


\section{Acknowledgements}

I am grateful to LTG Robert Brown, LTC David McHenry, and many other mentors and peers with whom I have been fortunate to share my ideas. Their constructive feedback on my thoughts and counterpoints to my arguments have given me the ability to think broader and deeper about the subject of this monograph. A special thanks to my father who taught me to know I know nothing, appreciate the immense power and value of inquiry, and comprehend the strength and satisfaction that comes from standing by conviction. Finally, my deepest gratitude to my wife and children for their patience and understanding of this demanding undertaking that has divided my attention for so long. 


\section{Contents}

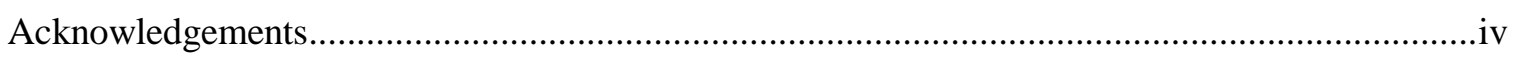

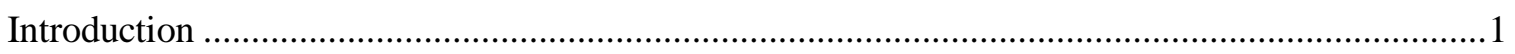

Officer Rank Flexibility and the Decentralized Nature of the Old Army ........................................ 10

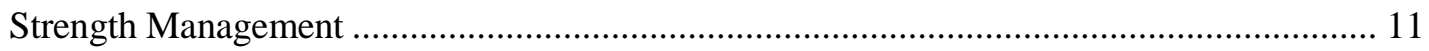

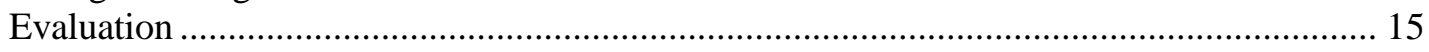

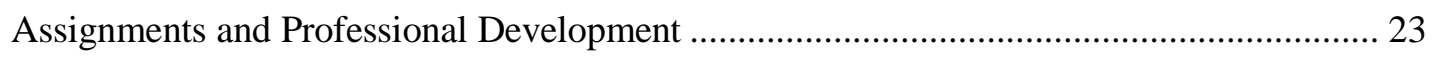

Centralizing Reforms and the Managerial Revolution.............................................................28

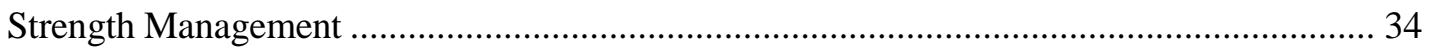

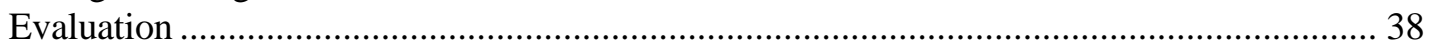

Assignments and Professional Development ................................................................ 45

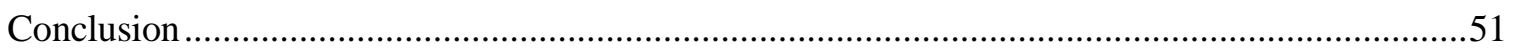

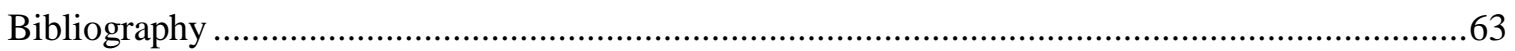




\section{Introduction}

Omnia mutantur, nihil interit [Everything changes, nothing perishes]

—Ovid, Metamorphoses

In 1885, Major General James H. Wilson, one of the most talented military critics in the United States and in the estimation of General U.S. Grant one of his most competent lieutenants, wrote a tribute to one of his subordinate officers. Wilson claimed the officer, "was as good an artillery officer as could be found in any country, the equal of any cavalry commander of his day, and...the best commander of a division of infantry in either the Union or the rebel army.” Wilson added, "He was incontestably the best tactician of either army... he could scarcely have failed as a corps or army commander had it been his good fortune to be called to such rank.” ${ }^{1}$ Some have referred to the officer, who also served as commandant of the United States Military Academy and the Army's superintendent of theoretical instruction, as the most influential young officer in the work of Army reform, a warrior prophet, an extremely logical and articulate officer with brilliance and considerable intellect, "the greatest military philosopher who has ever written in [the United States].”2 This highly acclaimed officer was Emory Upton. The distinguishing quality is that he achieved his accolades at a very young age: brevet rank of major general at a mere twenty-five years old, title of commandant at the age of thirty. Despite his apparent manifestation

${ }^{1}$ F.W. Beers, ed., Our County and Its People: A Descriptive Work on Genesee County, New York, (J.W. Vose \& Co., Publishers, Syracuse, N. Y. 1890), accessed October 1, 2014, http://www.onlinebiographies.info/ny/genesee/upton-e.htm.

${ }^{2}$ Samuel P. Huntington, The Soldier and the State; The Theory and Politics of CivilMilitary Relations, (Cambridge, MA: Belknap Press of Harvard University Press, 1957), 232; Robert Cassidy, "Prophets or Praetorians? The Uptonian Paradox and the Powell Corollary," Parameters 33, no. 3 (September 2003): 131; Brian McAllister Linn, The Echo of Battle: The Army's Way of War (Cambridge, MA: Harvard University Press, 2007), 49; Peter D. Skirbunt, “Prologue to Reform: The 'Germanization' of the United States Army, 1865-1898” (PhD diss., The Ohio State University, 1983), 175; Statement by Assistant Secretary of War Henry Breckinridge, Hearing Before the Committee on Military Affairs, 64th Cong,, 1st sess., January 12, 1916, 19. 
as a successful product of his professional system, Upton believed he had not attained the position he deserved and thus considered his life and career a failure. ${ }^{3}$ Upton sought to reform his beloved institution, to better optimize and reward talent and merit in particular. The essence of some of these reforms still exists in the contemporary Army. Yet an interesting paradox developed after his death: a talented individual like him may never have progressed to such influential position without the rank-flexible opportunities his contemporary system afforded, a condition that dissolved with implementation of concepts he championed. Hyper-professionalization of the Army officer corps resulting from turn of the twentieth century personnel reforms reduced the flexibility and diversity of the previous system that permitted individuals like Upton to ascend quickly to rank commensurate with their level of talent.

The period of the 1890s-1920s represents an extraordinary era for the US Army in which a shift of professional commitments occurred; a time one historian defined as "The Army's Renaissance.”4 Internal and external observation and criticism, Progressive ideology, and the Second Industrial Revolution influenced the United States Army to break with its past in terms of military administration. The changing social values, the "new attitude" of an industrialized nation precipitated “revolutionary” changes in military policy. ${ }^{5}$ In scientific philosopher Thomas Kuhn’s terms, this period was revolutionary, a transformative episode that represented a shift of

\footnotetext{
${ }^{3}$ Stephen E. Ambrose, Upton and the Army (Baton Rouge, LA: Louisiana State University Press, 1964), vii and 3; Edward M. Coffman, The Old Army: A Portrait of the American Army in Peacetime, 1784-1898 (New York: Oxford University Press, 1986), 273-274; Graham A Cosmas, An Army for Empire: The United States Army in the Spanish-American War (College Station, TX: Texas A\&M University Press, 1998), 39. Frustrated, depressed, and possibly suffering from a brain tumor, Upton committed suicide in 1881.

${ }^{4}$ William A. Ganoe, The History of the United States Army, rev. ed. (Ashton, MD: Eric Lundberg, 1964), 355.

${ }^{5}$ John W. Chambers II, “Conscripting for Colossus: The Progressive Era and the Origin of the Modern Military Draft in the United States in World War I," in The Military in America: From the Colonial Era to the Present, ed. Peter Karsten (New York: Free Press, 1980), 298; Skirbunt, "Prologue to Reform," 178.
} 
paradigms. ${ }^{6}$ The changes of this era went beyond complementing previously accepted norms and rules and altered the activity of traditional officer management. Historian John Lewis Gaddis would explain this moment in history as a "phase transition," a critical point when the stable became unstable. ${ }^{7}$ Not surprisingly, this era covers the typical time-period required for incubating and adopting basic innovation. ${ }^{8}$

Following the termination of the Spanish-American War, the Army's efforts to organize more effectively to meet the expanding boundaries of military enterprise resulted in a more professional and managerial military officer. ${ }^{9}$ Reformers such as Secretary of War Elihu Root and many “Progressives in uniform,” "armed progressives,” or “neo-Hamiltonians” assumed an army of mobilized amateurs could not master the complexity of modern warfare. ${ }^{10}$ Advocates for change believed the next war would require officers with managerial skills equivalent to those displayed by financial magnates and captains of industry. ${ }^{11}$ In 1908, Army Captain Matthew Steele observed, "Never before today was the conduct of war so much like the conduct of any

${ }^{6}$ Thomas S. Kuhn, The Structure of Scientific Revolutions (Chicago, IL: University of Chicago Press, 1970), x. Paradigms are model problems and solutions to a community of practitioners.

${ }^{7}$ John L. Gaddis, The Landscape of History: How Historians Map the Past (New York: Oxford University Press, 2002), 98.

${ }^{8}$ Peter M. Senge, The Fifth Discipline: The Art and Practice of the Learning Organization (New York: Doubleday/Currency, 2006), 6.

${ }^{9}$ Morris Janowitz, The Professional Soldier (New York: Free Press, 1971), $24,26$.

${ }^{10}$ John M. Gates, Schoolbooks and Krags: The United States Army in the Philippines, 1898-1902 (Westport, CT: Greenwood Press, 1973), chap. 2; Jack C. Lane, "The Military Profession’s Search for Identity,” Marine Corps Gazette, 57, no. 6 (June 1973): 36-42; Peter Karsten, “Armed Progressives: The Military Reorganizes for the American Century,” in The Military in America, ed. Peter Karsten (New York: Free Press, 1980),239; Allan Reed Millett, Peter Maslowski, and William B. Feis, For the Common Defense: A Military History of the United States from 1607 to 2012, 3rd ed., (New York: Free Press, 2012), 242; Huntington, The Soldier and the State, 270. Huntington's index does not contain the term "Progressives" but it seems clear he was referring to the same concept.

${ }^{11}$ Linn, The Echo of Battle, 52. 
other gigantic business...never before was a technical knowledge of the duties...so necessary to the agents of the business."12 Reformers embraced a "managerial revolution” that emphasized the need for competent executives who fit defined and standardized skills and efficiency for particular positions. ${ }^{13}$ When it came to estimating military efficiency, the professionalizing Army refocused emphasis from "personal characteristics and demonstrated ascendency over the minds and wills of men” to "mere professional knowledge and the ability to pass good examinations.”14 Consequently, the Army officer management system transformed from an intimate and personal activity into a centralized, industrial process bound within a business organization framework, a progression that tended to enhance a corporate existence for the officer corps. ${ }^{15}$ The extensive professionalization the United States Army underwent in its commissioned officer corps at the turn of the twentieth century fundamentally transformed the organization and culture of American land forces. ${ }^{16}$

The twenty-first century United States Army officer corps is the legacy of extensive reforms instituted by modernists during the Progressive Era who sought to centrally manage the personnel system of the emerging large-scale organizations intrinsic to warfare through reason

\footnotetext{
${ }^{12}$ Matthew F. Steele, “The Conduct of War,” Journal of the Military Service Institution of the United States 42, no. 151 (January-February 1908): 26.

13 “The 'managerial revolution' of the Progressive Era dramatically altered [officers' career] clocks, the nature of combat, and the manner in which the institutional apparatus of the Army was managed, thereby changing the nature of officership in the U.S.” Victor P. Corona, “Career Patterns in the U.S. Army Officer Corps," Public Organization Review 11, no. 2 (2011): 129.

${ }^{14}$ Linn, The Echo of Battle, 104-105.

15 "Expertise, corporateness, and professional responsibility became the hallmarks of the new military professionalism.” William Geffen, “Introduction,” in Command and Commanders in Modern Warfare: Proceedings of the Second Military Symposium, US Air Force Academy, ed. William Geffen (Washington, DC: Government Printing Office, 1969), 4; Huntington, The Soldier and the State, 244.

${ }^{16}$ Timothy J. Kane, Bleeding Talent: How the US Military Mismanages Great Leaders and Why It's Time for a Revolution (New York: Palgrave Macmillan, 2012), 112. Kane asserts Secretary Root's reforms are "where we see the firm foundation of the current personnel system."
} 
and scientific method. However, in a complex system comprised of thousands of individuals, actions have long-ranging effects, some of which are unintended. When change occurred, aspects and advantages of decentralized officer management ebbed to obsolescence. What then were the dynamics of the prevailing system and to what extent did advocates for change really understand them? Were the problems reformers observed and criticized actually just misinterpreted manifestations of the dynamics? Did this condition of failed systems thinking "lure policy makers into interventions that focused on obvious symptoms not underlying causes, which produced short-term benefit but long-term malaise, and fostered the need for still more symptomatic interventions" over the remainder of the century and into the next? ${ }^{17}$

“Although historians have generally concentrated on the proximate causes rather than on the underlying reasons, neither can be fully understood without the other,” historian John Chambers claims, "New Army policies were a sign of a new America." ${ }^{\text {18 }}$ Historic researchers prepare narratives by moving backward, beginning with a structure or phenomenon and then tracing its processes or antecedents to a cause at which point any further investigation has diminished relevance. While context does not directly cause occurrences, it can certainly determine consequences. ${ }^{19}$ This paper examines the conditions of the era in the search for, as historian Clayton Roberts states, "the ultimate cause at the point where the state of affairs, whose alteration [sought] to explain, flourished." ${ }^{20}$ This analysis focuses on the history of the earlytwentieth century United States Army professionalization reforms in order to grasp the fundamental shift in the focus of officer talent management and explain the origin of the modern

${ }^{17}$ Senge, The Fifth Discipline, 14-15.

${ }^{18}$ Chambers, “Conscripting for Colossus,” 298.

${ }^{19}$ Gaddis, The Landscape of History, 95-97.

${ }^{20}$ Clayton Roberts, The Logic of Historical Explanation (University Park, PA: Pennsylvania State University Press, 1996), 111. 
personnel system. Rather than aggregating individual causes looking for the principal reason for change, this paper examines the individual, institutional, cultural, and contextual factors present at many levels in order to link and bind actions and decisions that collectively generated a refocused officer system. An appreciation of the way the military organization functioned before and after the transition allows for a better understanding for those who still experience it, study it, and try to explain it.

The literature surrounding this era is remains generally divided between historical and sociological research. Edward Coffman's works provide historical documentation of the internal and external context for the Army before and after the Spanish-American War. Walter Millis and William Ganoe’s accounts are also vital historical work not only for their comprehensive content but also for their personal perspective as individuals whose early careers spanned the era of reform. Scholars such as Graham Cosmas, Russell Weigley, Peter Karsten, Allan Reed Millett, Peter Maslowski, and James Hayes offer a sound survey of Army history from which a researcher can draw evidence. Research by Weigley, Karsten, Stephen Ambrose, Todd Brereton, Timothy Nenninger, James Hewes, Jack Lane, John Gates, and James Abrahamson provide clear, historical perspective of the progressive reformers' motives and actions. The generally objective value of these works is complemented by the contributions of social military scholars including Morris Janowitz, Samuel Huntington, Brian McAllister Linn, and Donald Vandergriff, whose thoroughly researched but subjective (and controversial) perspectives on Army professionalism provide rounded perspective and structure to study the evolution of the American military institution during the Progressive Era. ${ }^{21}$

\footnotetext{
${ }^{21}$ For an explanation of the conflicting research and theses adopted by different researchers and historians regarding this era, see Edward Coffman, "The Long Shadow of The Soldier and the State,” Journal of Military History 55, no. 1 (January 1991): 69-82, Carol A. Reardon, "The Study of Military History and the Growth of Professionalism in the US Army Before World War I” (PhD diss., University of Kentucky, 1987), 4-5, and Peter J. Schifferle
} 
Collectively, these works refer to the transformation of Army officers from a heroic ideal to a manager. ${ }^{22}$ They acknowledge the reality that both the professional Army officer and the institution embody a mixture of manager and heroic elements and that the personnel system's focus on one leads to the neglect of the other. ${ }^{23}$ A gap in understanding exists between the "why and how" the heroic ideal held such prominence in the Old Army and the "why and how" the military manager supplanted it. Filling this logical space provides a critical retrospective understanding of the talent management crisis Army officers confronted at the time, a perspective that may prove useful to those interested in shaping the modern Army for its future.

To provide a common framework for contrasting officer management methods prior to and following the reforms, this monograph uses elements of the modern Officer Personnel Management System that equips the US Army with "an evolutionary system that balances the needs of the Army with the aspirations and developmental requirements of the entire officer corps.”24 The structure has six subsystems, four are necessary for this analysis. The subsystems, grouped into three categories, are as follows: strength management, evaluation, and assignments and professional development. Unlike the Old Army, the modern system operates in a centralized

“Anticipating Armageddon: The Leavenworth Schools and US Army Military Effectiveness, 1919-1945” (PhD diss., University of Kansas, 2002), 8-26; For a description of the disciplinary shift toward the study of "War and Society," attempting to place military institutions and events into ever broadening contexts, see Eliot A. Cohen and John Gooch, Military Misfortunes: The Anatomy of Failure in War (New York: Free Press, 1990), 39; Of all the researched works, Vandergriff's comes closest to the focus of this analysis. See "Chapter 2: The Minuteman, Emory Upton, and Elihu Root," in Donald E. Vandergriff, The Path to Victory: America's Army and the Revolution in Human Affairs (Novato, CA: Presidio Press, 2002).

${ }^{22}$ For example, Coffman and Millis have entire chapters titled "Managerial Revolution," while Janowitz claims the original purpose of military social research was to describe the transformational developments of the first half of the twentieth century that led to the modern military establishment and its struggle between heroic leaders and military managers.

${ }^{23}$ Janowitz, The Professional Soldier, 21-22; Linn, The Echo of Battle, 5-9.

${ }^{24}$ Department of the Army Pamphlet (DA PAM) 600-3, Commissioned Officer Professional Development and Career Management (Washington, DC: Headquarters, Department of the Army, February 2010), 11. 
manner. ${ }^{25}$ However, its universal purpose-acquiring, developing, utilizing, sustaining, promoting, and transitioning officers while operating as various factors including law, policy, and Army requirements constantly influence its environment-remains applicable even when analyzing the decentralized nature of talent management over a century ago.

The organization of this monograph is two sections. The first section explains the traditional decentralized concept of officer management by means of the four subsystems and provides an account of a common rank-flexible artifact, brevet promotion, present in the officer corps in the Old Army. ${ }^{26}$ This examination clarifies the general context and culture- or system dynamics - that permitted the proliferation and effectiveness of such a mechanism prior to the reforms. The second section reviews the administrative modifications during the "Managerial Revolution” prior to and following the Spanish-American War; changes that produced a centralized solution in response to perceived flaws in the existing system. This allows for consideration of the internal problems the Army sought to overcome (including regimental/branch parochialism, strife over promotion, seniority, and careerism) and visualization of th e approaches various reform-minded individuals and leaders employed to determine the desired future state of the Army officer corps. Examining this phase against the same four subsystems reveals the decline and virtual disappearance of rank-flexibility in the officer corps, a characteristic forfeited to developing the Industrial Army.

The contemporary United States Army officer corps is the legacy of progressive era reforms that discarded the decentralized and personal system of managing talent in favor of a

\section{${ }^{25}$ DA PAM 600-3, 36-37.}

${ }^{26}$ James G. Pierce, Is the Organizational Culture of the US Army Congruent with the Professional Development of Its Senior Level Officer Corps? (Carlisle, PA: Strategic Studies Institute, September 2010), 7. Artifacts are easily observable; however, they only provide a superficial glimpse of an organization's culture because the true significance or meaning that lies behind their use can be difficult to decipher and interpret. 
centralized system based on scientific organization and efficiency. The purpose of this study is to explain and understand that transformation rather than lay bare and condemn actions of a previous era. It emphasizes bottom-up analysis of the micro dynamics of individual behavior in history while considering top-down strategic forces, contexts, and conditions. ${ }^{27}$ Piecing together uneven and imperfect empirical evidence, this examination provides insight into an obscured and overlooked aspect of Army officer culture. ${ }^{28}$ In reference to the value of the era, historian Peter Skirbunt wrote, "If the United States wishes to benefit by studying its own history, the army reform movement of the nineteenth century...would serve as an excellent starting point."29 Examining and thinking critically about officer identity in the historical context of the time reveals key insights and allows for retrospective understanding. ${ }^{30}$ Making sense helps rationalize what people were, and are still, doing. Historical perspective helps to judge the behavior of the American Army and its officer corps. ${ }^{31}$ This monograph informs the first questions of sensemaking, “What was going on? How did we get here?” and should provoke reflection on a second but equally important question, "What do we do now?"32

${ }^{27}$ Corona, “Career Patterns,” 130-131.

${ }^{28}$ Reardon, "The Study of Military History," 4; Skirbunt, "Prologue to Reform,” 3-4; John M. Gates, "The Alleged Isolation of US Army Officers in the Late 19th Century," Parameters 10, (Spring 1980): 43-44. In reference to this era, Gates states, "Probably no era in the study of American history is in such a state of confusion, and many military historians might tend to shy away from such questions as whether or not one can speak of progressives, who they were (if they existed at all), what motivated the many Americans engaged in the varied efforts to come to terms with the disturbing implications of the urban-industrial society, and where their ideas may have originated...such difficult questions may be those which are most important to an understanding of the officer corps at the time...”

${ }^{29}$ Skirbunt, "Prologue to Reform,” 180.

${ }^{30}$ Karl E. Weick, Kathleen M. Sutcliffe, and David Obstfeld, “Organizing and the Process of Sensemaking,” Organization Science 16, no. 4 (July-August 2005): 409.

${ }^{31}$ Richard A. Gabriel and Paul L. Savage, Crisis in Command: Mismanagement in the Army (New York: Hill and Wang, 1978), 27.

${ }^{32}$ Weick, Sutcliffe, and Obstfeld, “Organizing and the Process of Sensemaking,” 413. 


\section{Officer Rank Flexibility and the Decentralized Nature of the Old Army}

In 1930, military historian C.O. Head observed:

methods of producing [officers] and selecting them for critical duties have varied considerably in the past, and never conformed to any fixed principle. With a civil government, quite properly jealous of its supremacy to military power, and varying in its foreign outlook, anything in the nature of definite military [personnel] policy has been impossible, and its lack has reacted on all features of the military machine. ${ }^{33}$

Though referencing his native British military, Head's remarks could very well have applied to the US Army, especially prior to progressive era reforms. He noted that officers traditionally progressed to the top ranks via various methods including possessing wealth, great personal charm, peculiar accomplishments, “an imposing breast of medals,” or influential friends. Respect and ability were highly prized, though they may have been indistinguishable from sycophancy and luck. He assessed that "without a definite military code and system, these factors produced a variegated effect” but he concluded that the officers served their country well and devotedly and "on the whole the results obtained from [the system] have been satisfactory.” Not surprisingly, elements of the Royal Army method closely mirrored characteristics of the US Army officer management system at the turn of the twentieth century. Within the traditional system, a great amount of flexibility existed for officers to achieve rank and position and it proved generally successful and effective.

The defining feature of Old Army officer professional management was its reliance on decentralized selection. Army officers generally remained in the same regiment, corps, or bureau throughout their careers. ${ }^{34}$ The Army placed dependence on—and confidence in—the reality that it dispersed authority to influence an officer's career status, schooling, command selection,

${ }^{33}$ Charles O. Head, The Art of Generalship (Aldershot, England: Gale \& Polden, 1930), 3.

${ }^{34}$ Cosmas, An Army for Empire, 13. 
retention and retirement, and promotion throughout the institution. ${ }^{35}$ Standardization in personnel management, rank and assignment in particular, was uncommon and highly variable and had positive and negative effects on each of the interrelated subsystems of officer personnel management. First, sparse and strictly limiting Congressional laws, policies, and budget had a considerable impact on strength management. The Army, left to manage its composition, focused on retaining proven talent. It increased stability through experience but produced generational clashes and amplified criticism of its inefficiency. Second, promotion authority resident within regimental and branch organization affected officer evaluations. Through methods of rank flexibility, the army optimized talent proficiently but the non-standardization and informality fostered an environment that engendered seniority and parochialism. Third, the modest size of the officer corps influenced assignments and professional development. By leaving officer progression unregulated and unprescribed, the institution encouraged creative, non-standardized, and developmental career paths that broadened its future leaders but lacked predictability that potentially limited individuals who did not possess necessary influence.

\section{Strength Management}

Prior to the 1890’s, Congress largely neglected its legal, budgetary, and policy role in managing the army, an era some have referred to as a "Dark Age" because of the lack of oversight. ${ }^{36}$ The composition and disposition of the Old Army remained anchored in public confidence that, when necessary, the institution could reconstitute into a monolithic fighting unit like the Union Army of the Civil War. ${ }^{37}$ Consequently, the regular Army operated with a small

${ }^{35}$ Reardon, “The Study of Military History,” 8-9.

${ }^{36}$ James E. Hayes, The Evolution of Military Officer Personnel Management Policies: A Preliminary Study with Parallels from Industry (Santa Monica, CA: RAND, 1975), vi; Ganoe, The History of the United States Army, 298, 356; Skirbunt, "Prologue to Reform,” 2.

${ }^{37}$ Skirbunt, "Prologue to Reform," 7. 
and scattered force. With an average of less than 30,000 soldiers (around 2,100 officers and 25,000 enlisted) spread out over about 255 posts, the Army generally remained occupied with the waning operational requirements of the Indian hostilities. Structurally, the highest organizational element was the regiment, a unit rarely assembled; a company was the usual garrison at a post. ${ }^{38}$ In the face of a diminishing and dispersed force structure and general detachment from public or legislative oversight, the Army sought to maintain its identity. ${ }^{39}$ The condition of having been "left to [its] own devices with minimum interference by the Congress" allowed the Army to maintain a sense of autonomy in managing internal affairs. ${ }^{40}$ Greater than any other period in its history, the composition of the officer corps in the late nineteenth century illustrates the Army's desire and effort to maintain tradition in the face of rapid modernization.

According to one historian, the Army of this period was "uncomfortably poised on the cusp of two eras." ${ }^{41}$ Another finds it surprising that this "imbalanced” officer corps "did not cause more disharmony than it did." ${ }^{42}$ The declining size of the force in the decades following the Civil War resulted in fewer vacancies in the upper ranks and the institution confronted the challenge of reducing the size of the Army without purging critical experience and talent. ${ }^{43}$ Faced with managing a mass of men who had served with distinction and rank in divisions and corps, the

\footnotetext{
${ }^{38}$ Hayes, The Evolution of Military Officer Personnel Management Policies, 67; Cosmas, An Army for Empire, 2; Russell F. Weigley, "The Elihu Root Reforms and the Progressive Era," in Command and Commanders in Modern Warfare: Proceedings of the Second Military Symposium, US Air Force Academy, ed. William Geffen (Washington, DC: Government Printing Office, 1969), 14.

${ }^{39}$ Cosmas, An Army for Empire, 24.

${ }^{40}$ Hayes, The Evolution of Military Officer Personnel Management Policies, 84-85.

${ }^{41}$ Todd R. Brereton, Educating the U.S. Army: Arthur Wagner and Reform, 1875-1905 (Lincoln, NE: University of Nebraska Press, 2000), xvii.

${ }^{42}$ Coffman, The Old Army, 223.

${ }^{43}$ Bernard Rostker et al., The Defense Officer Personnel Management Act of 1980: A Retrospective Assessment (Santa Monica, CA: RAND, 1993), 78; Hayes, The Evolution of Military Officer Personnel Management Policies, 78-79.
} 
institution permitted many to take a reduction in rank and static assignment in lower echelons to remain in the service. Though policy compelled senior officers to retire at age 64 after 1882, most Civil War veterans at the turn of the century still had five to ten more years of service left. As late as 1895, 271 Civil War veterans remained as company-grade officers and nine Civil War generals continued to serve. ${ }^{44}$ For many of these individuals, the Civil War was the defining professional crucible. As junior officers, they had proven their utility by wielding great authority and bearing significant responsibility and felt that natural process of aging should not diminish their relevance. ${ }^{45}$ They remained nostalgic for days past when reputation and rank was gained (and lost) candidly and felt the transforming system was a devious administrative attempt to cast them off and leave them behind. At the middle levels, officers were disillusioned and discouraged, stuck in a system stagnant by character but proven effective and appropriate to the American way of war. ${ }^{46}$ Junior officers, influenced by the novelty of progressive thought, chafed at the restrictions of the system that held seniority in such regard. Seeking opportunities for advancement and ways to remove the old guard, younger officers sought ways to steer the interwa r debate on military reform to efficiency, professionalism, and education. ${ }^{47}$ The further removed the traditional system was from the Civil War, the more its implicit benefits came under scrutiny and criticism.

Even more than the force of today, the Old Army valued and honored its "roots in the citizenry” but a shift away from the value and importance of volunteers created additional tension

${ }^{44}$ Coffman, The Old Army, 230

${ }^{45}$ Ibid., 215.

${ }^{46}$ Skirbunt, "Prologue to Reform," 4.

${ }^{47}$ Gerald F. Linderman, "The War and the Small-Town Community,” in The Military in America: From the Colonial Era to the Present, ed. Peter Karsten (New York: Free Press, 1980), 291; Reardon, "The Study of Military History,” 9-10. 
in the officer corps. ${ }^{48}$ By 1897, West Point graduates made up 60 percent of the officer corps (80 percent of its junior officers), civil appointees 30 percent, and "rankers" the remainder. ${ }^{49}$ This novel distribution of military educated professionals deviated from the volunteer and appointee model that dominated the composition of the officer corps in the second half of the nineteenth century. The evolving Army officer corps was imbalanced. Professional, academy-trained officers mingled with the oft-perceived amateur, unqualified, and irrelevant "ex-officers of volunteers. ${ }^{\text {50 }}$ Friction, reminiscent of that between youthful and aged officers, developed between graduates and non-graduates as well as among officers who had achieved rank by flexible or unconventional opportunities. Professional arguments raged around issues such as whether commissions should only go to West Pointers during peacetime. The situation reached a climax at the end of the century when over 1,000 new officer billets emerged, most going to graduates of military colleges, state colleges with military training programs, and volunteers or National Guard members. Only 22 percent of the lieutenants who entered between 1899-1902 were academy graduates. ${ }^{51}$ The stability brought about by retaining war-tested officers who had ascended by accomplishment or directly commissioning large numbers of civilians faced increasing criticism from formally trained and educated officers who felt the presence of unprofessionals bred inefficiency. One young officer complained that his superior officers who had considerable experience and many years of service were, "Fixed in their mental habits, slow to assimilate new ideas and critical of everything different from the methods of the 'old

${ }^{48}$ Carl H. Builder, The Masks of War: American Military Styles in Strategy and Analysis (Baltimore, MD: Johns Hopkins University Press, 1989), 19.

${ }^{49}$ John J. Lenney, Rankers: The Odyssey of the Enlisted Regular Soldier of America and Britain (New York: Greenburg, 1950), xvii. Ranker refers to a commissioned officer who has risen from the ranks by means of his own meritorious service and passing exacting examinations.

${ }^{50}$ Coffman, The Old Army, 223.

${ }^{51}$ Karsten, “Armed Progressives,” 266. 
army...”,52 The time (and place) for the valiant volunteer was nearing its end and the increasing cohort of formally educated and trained professionals believed they should fill the limited positions. ${ }^{53}$

Absent a standardized system of education and training, strength management in the Old Army revolved around maintaining stability by retaining experience. However, unclear policy and regulation concerning management of the composition of the officer corps led to an imbalanced force and increased tension between generations of officers. Most clearly, the army lacked an agreed-upon definition of what defined a professional officer in the evolving force. Though not necessarily ineffective, the multiple paths to achieving commission and rank ran contrary to the era of scientific and objective consistency and equality, an unacceptable situation for those steered by progressive thought. The army’s emphasis on sustaining and exploiting proven talent provided a comfortable and known level of experience but hindered its ability to acquire, develop, and transition talent efficiently.

Evaluation

In contrast to the massively expanded forces of the twentieth century and existing European armies of its day, the traditional regular US Army officer corps was small and intimate. Consequently, relationships and personal assessments of performance and potential, inside and outside the institution, mattered greatly and had an influence on the trajectory of an officer's career. The army relied on personal methods to determine the appropriate skills, experience, competencies, manner of performance, and demonstrated potential required of its officers.

\footnotetext{
${ }^{52}$ Quoted in Timothy K. Nenninger, “The Fort Leavenworth Schools: Post-Graduate Military Education and Professionalization in the US Army, 1880-1920” (PhD diss., University of Wisconsin, 1974), 332.

${ }^{53}$ Frederick B. Wiener, “Mex Rank Through the Ages,” Infantry Journal 54, (October 1943): 62.
} 
Dynamics outside of a standardized and centralized checklist usually factored into the identification and advancement of talented officers. The key advantage of this generally unconstrained process was its flexibility, especially in gaining (and losing) rank based on relevant assessments.

Reflecting the largely volunteer and non-standardized nature of the Army, individuals generally found the relationships among superiors and inferiors sufficiently flexible to permit a range of acceptable actions. ${ }^{54} \mathrm{~A}$ common assumption held that authority derived principally in the recognized qualities of the officer, rather than his rank. This did not imply casualness or lack of attention; discipline and technical proficiency mattered greatly. The Army concentrated on an officer's talent and character as the paramount qualities required for rank, whether military superiors or political figures acknowledged those attributes was largely irrelevant. Historian Gerald Linderman emphasizes, "Not even the most dedicated professionals yet conceived of the Army as a machine, or soldiers as cogwheels that could be made to rotate independently of individual will...success of an army flowed from the personal qualities of its members...”55 Historian Walter Millis explained in 1959, “the idea that the American soldier was simply a cog in a 'great machine' was by no means as acceptable in 1899 as it has become today." ${ }^{\text {„6 }}$ The army ascribed rank primarily by judging the individuals’ character. As General Maxwell Thurman remarked, “authority flows from competence, not rank." ${ }^{57}$ Rank and resulting influence came to those who displayed desired attributes, but it could just as swiftly be revoked. The system

\footnotetext{
${ }^{54}$ Gerald Linderman, “The Spanish-American War and the Small-Town Community,” in The Military in America: From the Colonial Era to the Present, ed. Peter Karsten (New York: Free Press, 1980), 279.

${ }^{55}$ Ibid., 290.

${ }^{56}$ Walter Millis, Arms and Men: A Study in American Military History (New York: G.P. Putnam’s Sons, 1956), 175.

${ }^{57}$ Quoted in Department of the Army Pamphlet 600-65, Leadership Statements and Quotes (Washington, DC: Headquarters, Department of the Army, November 1985), 20.
} 
encouraged filling specific positions with identified talent required and desired, not solely by the fact that an individual bore a specific rank. Consequently, flexibility in moving talent into positions and assigning rank ex post facto remained critical to the effectiveness of the entire institution. $^{58}$

Local military authorities, critical for flexibility in the officer corps, were indicative of the decentralized nature of promotion in the system. In the late nineteenth century, the regular Army was geographically dispersed; in 1888, there were around 120 stateside Army posts, compared to 77 by 1896, and only 40 by 1912. Based on this diaspora, the institution relied greatly on the semi-autonomous authority of local commanders. Commanders within regiments generally maintained control of career advancement including determining promotions up to captain. When debate surfaced concerning replacing the system in favor of a lineal promotion by seniority in branch, advocates of the traditional system highlighted the loyalty and reward of recognition by the local commander and the shared confidence in the semi-autonomous nature of command and control. Despite some limitations from its distributed nature, this system remained effective and productive. Major General William Harding Carter, a military reformer and trusted advisor to Root, even acknowledged that the "self-reliance which frontier training brought about...enabled the generals [in the Spanish-American War] to feel confident that each subordinate would lead” with confidence and competence. ${ }^{59}$

In contrast to a scientific and metric based evaluation standard, the officer corps of the era relied on a distributed, informal appraisal where character of the individual mattered most.

${ }^{58}$ Edward M. Coffman, The Regulars: The American Army, 1898-1941 (Cambridge, MA: Belknap Press of Harvard University Press, 2004), 149-150. In 1908, Lieutenant George Patton debated his branch choice with his eye on promotion timelines. His mentor Captain Charles Summerall (later Army Chief of Staff) advised him that promotions in peacetime did not mean much. When war comes, the powers that be disregard rank and look for someone who could win.

${ }^{59}$ William H. Carter, The American Army (Indianapolis, IN: The Bobbs-Merrill Company, 1915), 65. 
According to historian Edward Coffman, “The spirit of egalitarianism worked against the growth of any...group based on specialized skills." ${ }^{60}$ Many officers still professed to value certain autonomy in individual behavior, displayed best when Theodore Roosevelt, the embodiment of rugged individuality, occupied the White House. Roosevelt even championed a flexible system based on merit, writing, "We have got to push up our best men, wholly without regard for seniority..."61 For the Army, the best men were those whose technical deficiencies, to a degree, could be forgiven and rectified. It was cowardly, selfish, or immoral men who were unchangeable and unneeded. Ordinarily, the officer corps preferred generalists who could adapt and move among fields. In many cases, volunteers and appointees excelled where professional regulars faltered. Unfettered by constraints or concerns of a standardized career path, local commanders possessed great latitude in evaluating individuals to fit their most immediate requirements, rather than just having to make-do with the individuals they managed.

In the absence of an objective institutional standard by which to measure officers, flexibility in the ranks generally derived from performance and potential with the greatest test of performance being armed conflict. However, because of the flexible nature of the system, one could not simply assume that a man of higher rank had demonstrated ascendant military talent or grasped the principles of military leadership. With the proliferation of political appointees and civilian transfers in the ranks, the Army had in place a separate mechanism to denote those who had displayed such ability. The Army administratively used brevet rank to manage and acknowledge the ascendant talent assessed from within its ranks while bypassing legal and social impediments for doing so. In modern systems thinking, brevetting was a way to leverage talent within the complex personnel system. Brevetting applied change at the right point where

\footnotetext{
${ }^{60}$ Coffman, The Old Army, 269.

${ }^{61}$ Coffman, The Regulars, 52-53.
} 
minimum effort or cost could produce lasting, significant improvement to the individual agent and the organization as a whole. ${ }^{62}$

The US Army viewed brevetting as a system that "encourages rapid upgrading of officers who have distinguished themselves in action, and provides a means whereby promotional control can be properly decentralized to commanders in the field." ${ }^{63}$ The flexibility of brevetting aided it in serving the two aspects of rank, human and administrative, while providing an element of stability and advancement. ${ }^{64}$ Initially used in Europe in the seventeenth century, brevets were present in the Revolutionary War for the lateral transfer of civilians and later in the War of 1812 to recognize gallant actions or meritorious service. Often misunderstood by officers, biographers, and historians, brevet grades were not simply honorary or temporary titles with no practical authority. The army issued brevet grades as regular promotions that carried all the privileges of the regular rank. ${ }^{65}$ The key to the brevet system was that the rank was nominally higher than the substantive grade for which the individual received monetary compensation. Thus an officer received the rights and privileges of the rank but was only paid for his highest permanent rank. The officer reverted to that permanent grade after departing the position that required the brevet rank. To address the human aspect of rank, the authorization for lower commanders to assign brevet grades to those individuals actually performing jobs ensured individuals received prompt recognition for actual service and were given the status required of the grade. Frequently, less capable officers than desired or required were assigned higher jobs for the simple reason that

62 Senge, The Fifth Discipline, 64.

${ }^{63}$ US Army, “Appendix C: Discussion of Factors to be Considered in an Equitable Promotion System," in Systems of Temporary Promotion for Officers (Analytical Study, United States Army Command and Staff College, June 24, 1946), 2.

${ }^{64}$ F.S.G,. Piggott, “Promotion by Brevet,” Army Quarterly 59, (October 1949): 98-99.

${ }^{65}$ John H. Eicher and David J. Eicher, Civil War High Commands (Stanford, CA: Stanford University Press, 2001), 34. 
there were no better officers available. Regardless of his relative capability, if an officer was holding a particular position, he would hold the grade that goes with it—- “morale, prestige, and unit efficiency were at stake.”66 One officer observed, “Occasionally the system enabled a person of precociously outstanding military capacity to make his way speedily to the fore, to the benefit of the service as well as himself." ${ }^{67}$ Administratively, the government and the institution were not permanently encumbered with an uncontrollable number of officers promoted to higher rank but received the benefit of filling critical positions immediately and efficiently. Additionally, the use of the brevet grade came at no expense to the government.

The flexible system was not perfect. It did not eliminate favoritism nor serve well to identify the best officers for selection for permanent rank. ${ }^{68}$ Its lack of consistent regulation led to many irregularities. For example, it was not unusual for a man to hold several ranks simultaneously. Theoretically, an officer could hold up to four ranks at a time: regular Army rank, regular army brevet rank, volunteer rank, and volunteer brevet rank. An example of excessive rank-flexibility is Augustus Tassin, a volunteer Army lieutenant who earned a volunteer brevet to colonel (he claimed brigadier general) for his performance as a regimental commander in the Civil War. ${ }^{69}$ He ended the war as a volunteer colonel (at age 21) and the Army immediately appointed him a regular Army captain. When his commanding officer later declared him unfit, Tassin went to Europe and fought in the Franco-Prussian War, achieving the rank of brigadier general in the French Army. ${ }^{70}$ Upon returning to the United States, he re-enlisted in the Army as a

${ }^{66}$ US Army, “Appendix D: Proposed System to be Adopted by the United States Army,” in Systems of Temporary Promotion for Officers, (Analytical Study, United States Army Command and Staff College, June 24, 1946), 1.

${ }^{67}$ Reginald Hargreaves, “Ladder to the Stars,” Army 20, (September 1970): 43.

${ }^{68}$ US Army, “Appendix C,” 2.

${ }^{69}$ Coffman, The Old Army, 221.

${ }^{70}$ W.A. Curtis, “True Stories of Army Life,” The Era Magazine 15, (January-June 1905): 
private. Allegedly, General U.S. Grant recognized Private Tassin working as a chain bearer in 1873 and immediately appointed Tassin a lieutenant in his original unit. ${ }^{71}$ Tassin eventually $^{2}$ returned to his regular rank of captain by $1890 .{ }^{72}$ A more familiar example is George A. Custer who endured fluctuating status his entire career based on highly varying measures of performance, positive and negative associations with influential officers, and a penchant for poor judgment in personal matters. Quickly acquiring captain rank early in the Civil War, Custer reverted to first lieutenant rank when his commanding officer was relieved. Less than six months later, he received a volunteer brevet to brigadier general (at age 23) and eventually major general. After the war ended, he reverted to his regular army rank of captain. After a break in service, he received a regular brevet to major general for the 1867 Hancock campaign and served as a regular Army lieutenant colonel in various assignments before his combat death in $1876{ }^{73}$

While the variable rank system afforded a dynamic method of evaluation and talent optimization, its inherently inequitable and non-standard nature ran contrary to the growing progressive thought of the time. Critics also increasingly condemned the system’s perceived tolerance of parochialism and seniority. General (later President) James Garfield remarked, "Great abuse has gradually crept into the service in the matter of brevet promotions. Brevet rank...has come to have little meaning, except as an officer’s influence in Washington»74 while the general character of the regular Army promotion system remained sluggish. The average first

51.

${ }^{71}$ Curtis, “True Stories of Army Life.” Upon sighting Tassin, Grant reportedly remarked, "What, Augustus Tassin, colonel in the American Army and general in the French, a private soldier!”.

72 “Augustus Gabriel Tassin,” Arlington National Cemetery Website, May 13, 2006, accessed October 1, 2014, http://www.arlingtoncemetery.net/agtassin.htm.

${ }^{73}$ Robert M. Utley, Cavalier in Buckskin: George Armstrong Custer and the Western Military Frontier, rev. ed. (Norman, OK: University of Oklahoma Press, 2001), 40.

${ }^{74}$ Quoted in Wiener, “Mex Rank Through the Ages,” 60. 
lieutenant in 1891 was 45 years old; the youngest captain of artillery was older than the oldest captain of artillery in the British Army. ${ }^{75}$ However, little to no progression in rank did not construe failure or inefficacy. Often, like Custer, the men who held these positions were proficient and highly adept at their functions and were the ideal talent in proper position at the right time and their presence contributed greatly to the success of the entire regiment or bureau. In fact, hundreds of these officers were regulars and volunteers who had achieved brevets during conflict but opted to become regulars at lower rank rather than leave the force. ${ }^{76}$ Many of the officers in the Army at the turn of the century had earned their commission through distinguished service as volunteers and civilian appointees. For many, service had brought rank and reputation, a level of success and prestige they would have little hope aching in civilian life. Though some aspired to high rank, many others were content with company-grade appointments. As long as a man's talent and competence was sufficient for his rank and responsibilities, there was little systematic momentum to drive officers up or out of the organization.

The Army’s reliance on a decentralized assessment of the individual officer, judging a man against an undefined institutional norm as determined by the local commander and others with intimate knowledge of the individual, had proven successful. Even before he transformed the institution, Root testified before Congress, "There is not an abler body of men to be found anywhere in the world than the officers of the American Army."77 However, the increasing chorus of critics believed the vast inequality in standards and the minimally regulated system of evaluation was stifling progress in professionalizing the Army officer corps, compelling a need for more standardized measures to address these problems. The critics' answer to the perceived wasteful and corrupt system based on the priority of seniority and provincial favoritism should be

${ }^{75}$ Karsten, “Armed Progressives,” 259.

${ }^{76}$ Coffman, The Old Army, 218.

${ }^{77}$ Carter, The American Army, 219. 
methods that would focus on "personal efficiency," measuring employees' performance through new centralized and consistent scientific merit systems. ${ }^{78}$ The efficacy brought about by talent optimization in a flexible system came at the cost of efficiency, a critical proficiency required in large-scale industrial war.

Assignments and Professional Development

In the decentralized system, officer assignments generally emphasized meeting the needs of the various regiments and branches rather than fulfilling overall institutional requirements. Lack of a rigid, prescribed, and centrally controlled career path prompted officers to find a creative path of advancement that met their needs. Many officers used whatever political influence they could generate to their advantage in assignment and promotion matters. ${ }^{79}$ In this manner the Army was not isolated from society and reflected management practices of the time; an atmosphere of politics surrounded most facets of life in the nation. In the era that included individuals like Boss Tweed and organizations like Tammany Hall that assisted the interests of special groups, the political pressure to obtain rank or officer status by any means possible was reasonable. Though proximity to powerful figures often allowed staff officers in Washington D.C. the opportunity to master the art of political influence, at the turn of the twentieth century political power could influence an Army career even in the lower ranks and far from the reach of powerful figures. $^{80}$

Though leveraging influence for rank or position seems repugnant and self-serving, the practice did not necessarily equate to an ineffective officer corps. For every unproductive political

${ }^{78}$ Mordecai Lee, Bureaus of Efficiency: Reforming Local Government in the Progressive Era, (Milwaukee, WI: Marquette University Press, 2008), 24.

${ }^{79}$ Skirbunt, "Prologue to Reform,” 138; Coffman, The Old Army, 268; Gates, "The Alleged Isolation of US Army Officers in the Late 19th Century," 36; Cosmas, An Army for Empire, 2.

${ }^{80}$ Hayes, The Evolution of Military Officer Personnel Management Policies, 71. 
appointee, another served as an example of an individual who benefitted from the rank flexibility in the officer corps and served with distinction. For example, in 1899 President William McKinley personally interviewed an acquaintance who had waited outside his office for three days to see him. Upon being asked what rank he sought, the young second lieutenant responded, "Whatever you think I am capable of having, Mr. President." ${ }^{81}$ McKinley granted a volunteer captaincy. ${ }^{82}$ Within two months, Guy Henry Jr. was promoted to major and went on to lead volunteer troops successfully in the Spanish-American War, earning a Silver Star for gallantry. He would serve a distinguished career before retiring as a regular Army Major General in $1947 .^{83}$ Even General George Patton’s father used political influence to gain his son a senatorial appointment to West Point. ${ }^{84}$ However, the tradition of political influence faded as progressive thought permeated the ranks and many sought to purify the system.

A friend of a young officer of the time wrote, "Think of a man of his ability only a second lieutenant! Why does he remain in the Army?”85 Though the system was challenging to navigate and many officers were frustrated, it still provided possibilities for young officers with talent. Many of these aspiring officers found their own ways to make their mark in the army. Rather than being bound to a centralized and top-down driven career path, young officers took divergent paths to best utilize their unique talents and receive notice. Four examples of individuals who advanced within the rank-flexible opportunities of the era are John J. Pershing, Tasker Bliss, Leonard Wood, and Frederick Funston. Pershing seriously considered resigning his

${ }^{81}$ Guy V. Henry Jr., “A Brief Narrative of the Life of Guy V. Henry Jr.,” (Carlisle, PA: US Army Military History Institute, 1965), 22.

${ }^{82}$ Coffman, The Regulars, 16.

83 “Guy Vernor Henry, Jr.” Arlington National Cemetery Website, November 11, 2007, accessed October 1, 2014, http://www.arlingtoncemetery.net/ghenryjr.htm.

${ }^{84}$ Coffman, The Regulars, 145.

${ }^{85}$ Karsten, “Armed Progressives,” 262. 
commission due to the slow progression, but demonstrated leadership in combat combined with broadening assignments (and a marriage to the daughter of Senator Francis Warren, chairman of the US Military Appropriations Committee) eventually led to a three rank promotion from captain to brigadier general in $1906 .^{86}$ Bliss spent twenty-three years in the Commissary Department and worked as an administrator carding and tabulating officer efficiency records in the War Department prior to jumping from major to brigadier general in $1902 .{ }^{87}$ Wood, a medical doctor who earned a Medal of Honor leading infantry troops, leaped from captain to brigadier general after commanding troops (including personal friend Theodore Roosevelt) as a volunteer colonel. ${ }^{88}$ Denied admission to West Point for failing the admissions test, Funston served as a journalist, botanist, surveyor, trainman, volunteer for the Cuban Revolutionary Army, and US volunteer colonel, before earning the Medal of Honor and becoming the youngest general in the army at the time by receiving brigadier general rank at the age of 35 in $1901 .^{89}$

Conspicuously absent from the careers of these individuals was standardized professional military education after commissioning. Though all advanced military education during their career-Pershing was a professor of military science, Bliss instructed at the Naval College, Wood laid the foundations for the Reserve Officer Training Corps, and Funston served as commandant at Fort Leavenworth, Kansas—none was a product of or benefitted from a structured progression of professional military schooling. ${ }^{90}$ Though the Old Army recognized the growing need for

${ }^{86}$ John J. Pershing, My Life Before the World War, 1860-1917, ed. John T. Greenwood (Lexington, KY: University Press of Kentucky, 2013), 84.

${ }^{87}$ Karsten, “Armed Progressives,” 262.

88 "Major General Leonard Wood" in Biographical Sketches of Distinguished Officers of the Army and Navy (New York: L.R. Hamersly, 1905), 202-208.

89 “Fredrick Funston Papers: Collection 33,” Kansas Historical Society, accessed October 1, 2014, http://www.kshs.org/p/frederick-funston-papers/14027.

${ }^{90}$ Pershing, My Life Before the World War, 81; Huntington, The Soldier and the State, 242; From statements made by Maj. Gen. Leonard Wood, Senate Subcommittee on Military 
educating its officers, it chose to approach the matter in its traditional decentralized manner. The various bureaus, determined to preserve their autonomy, founded separate schools for their arms but resisted any unified school for the service. ${ }^{91}$ Though young officers believed it was to their advantage to attend, senior officers and the institution in general did not yet recognize the value, particularly of a combined college. ${ }^{92}$ Students were selected largely upon the recommendation of their superiors, rather than by competitive examination, leading to remedial schools for semiliterate officers that lacked any real joint and theoretical instruction. ${ }^{93}$ To graduate or simply to be published on the list of entrants was a source of pride but the Army system never made attendance an absolute prerequisite for advancement. ${ }^{94}$

Criticisms and reforms put forward by progressives in and out of uniform focused on a system they viewed as inefficient, parochial, and limiting. Detractors contended it was heavily influenced and characterized by the reality that only seniority or its variations mattered. ${ }^{95}$ Despite these criticisms, the US Army officers acquired and developed under the traditional officer management system were still competent and professional at the beginning of the twentieth

Affairs and the House Committee on Military Affairs, 64th Cong,, 1st sess., December 18, 1916 and January 31, 1917, 284; "Fredrick Funston Papers: Collection 33.”

${ }^{91}$ Martin van Creveld, The Training of Officers: From Military Professionalism to Irrelevance (New York: Free Press, 1990), 57. The School of Application for Cavalry and Infantry established at Fort Leavenworth in1881 can be considered an exception. However, truly open and unified schools such as the Army School of the Line, Army Staff College, and Army War College would not come about until after the Spanish-American War.

92 van Creveld, The Training of Officers, 60; Coffman, The Old Army, 274-276.

${ }^{93}$ Philip C. Cockrell, “Brown Shoes and Mortar Boards: US Army Professional Education at the Command and General Staff School Fort Leavenworth, Kansas, 1919-1940" (PhD diss., University of South Carolina, 1991), 9-11.

${ }^{94}$ van Creveld, The Training of Officers, 60.

${ }^{95}$ Sean C. Bernabe, "Changing the Officer Promotion System to Support Unit Focused Stability (UFS)” (SAMS Monograph. United States Army Command and General Staff College, 2005), 37; Rostker et al., The Defense Officer Personnel Management Act of 1980, 78; Hayes, The Evolution of Military Officer Personnel Management Policies, 70. 
century. ${ }^{96}$ Even though many officers had achieved position and status by means of rank flexible methods or political influence, the Army remained effective overall. In 1893, Brigadier General Wesley Merritt wrote, "With the officers of the army as a body...there is no shortcoming. Whether graduates of the Military Academy... or selected for their energy, capacity, and brilliancy in actual service, they are by common consent equal to the officers of the best European armies."97 Senator Henry Cabot Lodge praised the actions of American officers at the 1898 Battle of San Juan Hill, declaring "the flower of the American standing army...[attempted] something which the best military critics would declare well nigh impossible...The American army did it."98 British Major General E.T. Hutton remarked that the American army "is one of unquestioned excellence in...general military efficiency."99 Despite these realities, even senior leaders discerned that efficiency was dependent on administration and the winds of change were shifting the focus of officer management. General Carter conceded, "War has become a complicate and absorbing science demanding a knowledge of a vast array of principles and details on the part of those responsible for the administration of armies." ${ }^{100}$ The imminent transformation is best described by historian Graham Cosmas’ observation that “the Regular Army's established organizational and strategic theories were fated to collide disruptively with the political,

${ }^{96}$ Cosmas, An Army for Empire, 324-325. The condescension of the new Regulars and misuse of old army officers and Civil War veterans may have reduced efficiency and prevented the most effective use of their knowledge and talents during the Spanish-American War.

${ }^{97}$ Wesley Merritt, “The Army of the United States” in The Armies of Today: A Description of the Armies of the Leading Nations at the Present Time (New York: Harper \& Brothers, 1893), 3. Merritt concluded with a progressive tone late in his essay by acknowledging the "modifications" necessary to prepare for "the modern army", 53-54.

${ }^{98}$ Henry Cabot Lodge, “The Spanish-American War,” Harpers New Monthly Magazine 98, no. 586 (May 1899): 848.

${ }^{99}$ Carter, The American Army, 83-84.

${ }^{100}$ Ibid., 182. 
diplomatic...realities...”101 The efficacy of leading troops would no longer be the primary characteristic of officers; efficient management would be the discriminator and a centralized authority would be the determiner.

\section{Centralizing Reforms and the Managerial Revolution}

Regarding the state of the United States military, sociologist C.W. Mills wrote in the mid-twentieth century, “The military order, once a slim establishment...fed by state militia, has become the largest and most expansive feature of government, and...now has all the grim and clumsy efficiency of a sprawling bureaucratic domain." ${ }^{\text {"102 }}$ What developments occurred in the preceding decades led Mills to such a conclusion concerning military administration? A valid starting point for discussion requires examining the professionalization of the military into the centralized bureaucracy Mills indicts.

The precise origin of US Army professionalization has evolved with debate but nearly all historians trace efforts toward officer professionalization into the pre-Civil War era. Most, including historian Edward Coffman, agree that professionalism emerged in the last three decades of the nineteenth century. Disagreement exists concerning the level of professionalization existent in the United States Army at the turn of the century. ${ }^{103}$ To the international community at the time, the late-nineteenth century United States Army appeared amateurish. In1897, the German General Staff went as far as excluding the US Army from its published survey list of operational world military forces. ${ }^{104}$ Domestically, the press and public of the time viewed the hallmarks of

${ }^{101}$ Cosmas, An Army for Empire, 62.

${ }^{102}$ C. Wright Mills, The Power Elite (New York: Oxford University Press, 1956$), 7$.

${ }^{103}$ See Coffman, The Old Army, 269; Michael R. Matheny, Carrying the War to the Enemy: American Operational Art to 1945 (Norman, OK: University of Oklahoma Press, 2011), 18; William B. Skelton, An American Profession of Arms: The American Officer Corps, 17841861 (Lawrence, KS.: University Press of Kansas, 1992), 362.

${ }^{104}$ Millett, Maslowski, and Feis, For the Common Defense, 250; Skirbunt, "Prologue to 
the War Department as "bungling and inefficiency." 105 These perceptions of the condition of the officer corps derive from a misunderstanding of the unique character of the United States Army at the turn of the twentieth century. As outlined in the previous section, the Army officer corps was professional in its own way, designed for the Army the nation required at the time. Officers in the Old Army were more comfortable being a small fraternity of specialists who worked alongside talented amateurs from other backgrounds rather than depending primarily on institutionalized products of a bureaucratic system. However, conditions emerged at the turn of the century that required the Army to institute reforms and fundamentally altered its view of professionalism.

Crises are a necessary precondition for the emergence of phase transition. They propagate change by concentrating interest on a narrow area of trouble and create self-awareness of evolving conditions. Professional communities must then continually strive to bring theory and fact into closer agreement to solve a problem for whose very existence the validity of the existing paradigm must be assumed. ${ }^{106}$ The Army reformers of the Progressive Era who emerged during the transition period at the turn of the century recognized such a crisis. ${ }^{107}$ They had closely observed other armies such as the Germans who characterized the most successful model of efficiency and organization combined with progressive and innovative thought. ${ }^{108}$ The SpanishAmerican War produced effects reformers believed potentially discredited traditional theories of

\section{Reform,” 2.}

${ }^{105}$ Millett, Maslowski, and Feis, For the Common Defense, 259.

${ }^{106}$ Kuhn, The Structure of Scientific Revolutions, 80.

${ }^{107}$ One can argue that reformers were influenced greatly by the fin de siècle of the period. Literally, "fin de siècle" refers to the end of a century, yet at the end of the 19th century, the term broadly applies to a whole set of artistic, moral, and social concerns. To describe something as a fin de siècle phenomenon invokes a sense of the old order ending and new, radical departures. See Ruth Livesey, "Fin de Siècle," Oxford Bibliographies, accessed October 1, 2014, http://www.oxfordbibliographies.com/view/document/obo-9780199799558/obo-97801997995580030.xml.

${ }^{108}$ Skirbunt, "Prologue to Reform," 8. 
officer management, validated new ideas, and catalyzed a complete transformation of the institution. They recognized the need to educate and train officers not only to lead but to manage the ever larger armies of the era. ${ }^{109}$

Following the Spanish-American War, the American government recognized its growing role as a world power and accordingly assumed military action beyond the nation's borderswhether limited or total in nature-would require larger and more effective forces and an increased dependence on the regular army for tasks beyond the continental United States. A constabulary policy would no longer suffice. The new mission required the nation to defend new territory in the Pacific and Caribbean (including the Panama Canal), a situation that necessitated prompt military reform. ${ }^{110}$ Compounding the urgency to reform, the war against Spain revealed serious weaknesses in organization and personnel. ${ }^{111}$ Sometimes a severe deficiency in organizational structure can be recognized even if it does not result in defeat. ${ }^{112}$ Despite operational success, reports and commissions, most notably the Dodge Commission report, led to a judgment that the Army was unprepared to manage the large-scale force required for modern war. ${ }^{113}$ In response, President McKinley replaced Secretary of War Russell Alger with someone

${ }^{109}$ Matheny, Carrying the War to the Enemy, 19.

${ }^{110}$ Skelton, An American Profession of Arms, 362; Millett, Maslowski, and Feis, For the Common Defense, 282-285.

${ }^{111}$ John Masland and Laurence Radway, Soldiers and Scholars: Military Education and National Policy (Princeton, NJ: Princeton University Press, 1957), 83; Skirbunt, "Prologue to Reform,” 159-160.

${ }^{112}$ Cohen and Gooch, Military Misfortunes, 243.

${ }^{113}$ Cosmas, An Army for Empire, 297-298; Robert C. Kennedy, "Who Is This Criminal?,” HarpWeek (2001), accessed October 1, 2014, http://www.nytimes.com/learning/general/onthisday/harp/0813.html. The final report of the Dodge Commission criticized the War Department's overall lack of efficient administration and discipline during the war, but pointed to longstanding organizational problems in the US military as the basic culprit. Their findings helped secure passage of a military reform bill; Cosmas, $A n$ Army for Empire, 316; For a strong summary rebuttal to conventional argument that faults the ineptitude, inadequacy, and failures on the War Department, see the introduction to Cosmas, An 
who had a sound understanding of industrial practices rather than a military expert: negotiator and corporation lawyer Elihu Root.

According to biographer Richard Leopold, Root was the perfect solution, a "first-class lawyer” with "extraordinary talent for finding workable solutions to technical and complex problems."114 More importantly, Root was an excellent administrator who had the ability to "understand the thinking of and to maintain the unqualified respect of the professional soldier."115 Root assumed his position at a decisive stage in the Army's growth and development. and set an immediate and cohesive agenda to reform the Army. ${ }^{116}$ Leopold wrote, "Whether he realized it or not, his chief aim was to make [the Army] function in an age of corporate leviathans and...survive in a world of competing power."117 Styled "the personification of capitalistic efficiency,” Root initiated the efforts to confront and overcome the Army’s developing challenges of quantity and quality of officers in the first quarter of the twentieth century ${ }^{118}$

In response to a perceived crisis, the institutional army under Root and fellow reformers seized the opportunity, reorganized, and remodeled to a modern, professional warfighting organization. ${ }^{119}$ Reformers ambitiously sought to claim unchallenged intellectual authority over

Army for Empire, xv-xviii.

${ }^{114}$ Richard W. Leopold, Elihu Root and the Conservative Tradition (Boston: Little, Brown, 1954), 6.

115 Ibid., 25.

${ }^{116}$ Cosmas, An Army for Empire, 320.

${ }^{117}$ Leopold, Elihu Root, 195.

${ }^{118}$ Karsten, “Armed Progressives,” 263.

119 There is debate among scholars whether Root was truly a Progressive. Biographer Richard Leopold claims, "There is no evidence that, prior to March 1909, Root was interested in or influenced by the writings that underlay progressivism.” Russell Weigley notes, "Elihu Root was only in a very limited degree a Progressive.” Andrew Bacevich counters, "Root's achievements were once interpreted as those of an exemplary conservative somehow surviving in a flood of Progressivism. More recently, however, historians have recognized that the Root reforms themselves were indistinguishable from the main thrust of Progressivism.” Leopold, 
military affairs even in the face of American tradition that was wary of increased military professionalism. ${ }^{120}$ Citing a shift in rhetoric of essays published in Journal of Military Service Institution between 1895 and 1905, military sociologist Morris Janowitz believes this period represents the beginning of a more rational and managerial approach to the problems of organizing men for combat. ${ }^{121}$ Within a decade, the army was well into the process of reorganizing into a large-scale modern institution and implementing changes to increase efficiency, making tentative but steady reforms to prepare its officer corps and organization for modern warfare. ${ }^{122}$ At this critical point in institutional history, the Army dealt with its rapidly rising scale of manpower as it simultaneously tried to shape the qualities of the individuals tasked to lead the expanding organization. The army "had to confront its managerial dilemma even before its industrial organization developed a concern with rationalizing its ‘human relations.”,123 Specifically, the army had to struggle with a problem intrinsic for adaptation in a complex environment. Success for the organization depended on the fine-scale complexity of its individuals and the large-scale behavior it requires to survive. ${ }^{124}$ Thus, the Army had to balance quantity and quality in a new manner to adapt successfully to industrial warfare. The primary solution for accomplishing the transformation was centralization. ${ }^{125}$

Elihu Root, 72; Weigley, “The Elihu Root Reforms and the Progressive Era,” 12; Andrew J. Bacevich, Jr., "Progressivism, Professionalism and Reform,” Parameters 9, no. 1 (1979): 67; Also see, Robert Wiebe, The Search for Order (New York: Hill and Wang, 1967), 149.

${ }^{120}$ Reardon, "The Study of Military History," 1-2; Millet, Maslowski, and Feis, For the Common Defense, 293; Huntington, The Soldier and the State, 233; Skirbunt, "Prologue to Reform," 141.

${ }^{121}$ Janowitz, The Professional Soldier, 38-39.

${ }^{122}$ Millett, Maslowski, and Feis, For the Common Defense, 297.

${ }^{123}$ Janowitz, The Professional Soldier, 38-39

${ }^{124}$ Yaneer Bar-Yam, Making Things Work: Solving Complex Problems in a Complex World (Cambridge, MA: NECSI, Knowledge Press, 2004), 67-69.

${ }^{125}$ Cosmas, An Army for Empire, 20-21. Cosmas argues that a form of centralization 
Historian Martin van Creveld's assessment of Root embodies the concept behind the new approach to management of military officers, "Root was a centralizer by inclination. His principal concern was to end the dominance of the bureaus and create the machinery by which a muchexpanded army...could be managed.”126 Consolidated selection and administration of its officers became the defining feature of the modern Army officer professional management system. Through centralized selection, the Army gathered the authority to influence an officer’s career status, schooling, command selection, retention and retirement, and promotion to the institutional level. Standardizing personnel management, rank, and assignment in particular, allowed for universality, stability, and predictability while changing the focus and product of the officer corps. However, as transitions occur, knowledge and ideas are slowly gained, accepted, and assimilated but only by “discarding some previously standard beliefs or procedures and, simultaneously, by replacing the components of the previous paradigm with others.”127 Homogenizing the officer corps had positive and negative effects on each of the interrelated subsystems of officer personnel management. First, a massive increase in authorized force levels affected strength management. The Army, facing an expansion in size, restructured and reorganized to better control the growing leviathan while removing the autonomy and authority previously afforded to local commanders. Second, centralizing, standardizing, and strictly formalizing promotion authority affected officer evaluations. By reducing the opportunity for rank flexibility, the army efficiently gained a predictable and reliable officer product but lost its proficiency at optimizing its talent. Third, the emphasis on a standard professional officer corps affected assignments and professional development. By formalizing and regulating the education

began even prior to the Spanish-American War and may have been a contributing factor to the disorganized actions early in the conflict.

${ }^{126}$ van Creveld, The Training of Officers, 60.

${ }^{127}$ Kuhn, The Structure of Scientific Revolutions, 9, 66. 
and assignment process, the army increased predictability and limited the clout of external influence on officer progression, but also restricted the available paths available to broaden its future leaders.

\section{Strength Management}

The United States traditionally maintained a small peacetime constabulary force and extemporized fighting forces as needed during periods of war. ${ }^{128}$ When the Army organized to go to war in April 1898, its regular-troop strength stood at 28,000. The Army deliberately intended this force of hollow formations to serve as the national repository of military knowledge that could quickly receive volunteers and conscripts and rapidly transform them into full strength and trained units. ${ }^{129}$ As military planners prepared for the Spanish-American War, they realized a need for a much larger force to meet the evolving operational environment and requested a permanent expansion to 104,000 troops. Lawmakers ultimately approved a regular Army of only 67,000 men; the remaining troops materialized from federal volunteers and volunteers from state militias under their own officers and different personnel management systems. Notably, President McKinley had authority to appoint all volunteer staff and general officers, while governors appointed any other officers to lead the expanding mass of troops. ${ }^{130}$ By the end of the war, in addition to 263,000 troops, the Army was conducting operations with a mix of 11,100 “professional” and "unprofessional” officers. This mixture of experts and amateurs inevitably led to many of the personnel management issues cited by external observers. ${ }^{131}$ The army would

\footnotetext{
${ }^{128}$ Millett, Maslowski, and Feis, For the Common Defense, 241; Cosmas, An Army for Empire, 9.

${ }^{129}$ Michael A. Bonura, Under the Shadow of Napoleon: French Influence on the American Way of Warfare from the War of 1812 to the Outbreak of WWII (New York: New York University Press, 2012), 162-163; Cosmas, An Army for Empire, 36-37.

${ }^{130}$ Millett, Maslowski, and Feis, For the Common Defense, 257.

${ }^{131}$ For an essay on the contrast of the localistic National Guard and the cosmopolitan,
} 
redress this disparity in quality, but only after a stable and acceptable troop-level was assured. Aware of the need to prepare for such a situation again, Root initially focused on managing Army manpower. He quickly argued for and received an increase in permanent peacetime force levels from 28,000 to 60,000 by 1901. By 1904, the Army consisted of 50,000 enlisted troops and 5,000 officers spread over forty localities. ${ }^{132}$

Rapid expansion in peacetime caused managerial difficulties just as it had during the Spanish-American War. In 1902, Root acknowledged a significant flaw in control, “when we come to the coordination and direction of all [military and national] means and agencies of warfare, so that all the parts of the machine shall work together, we are weak."133 The growth and management of the Army paralleled the experience of private enterprise where industrialization was resulting in increasingly centralized authority over individual and corporate activities throughout American life. The scale of industrialization changed the character of modern warfare, demanding greater efficiency and control over personnel and materiel. Unlike previous administrators, Root and successive rationalist or modernist reformers emphasized the need to tighten executive control over the expanding forces by centralizing control and substituting rational order and regulation from the top down for previously unregulated or loosely managed activities. ${ }^{134}$ For many industrialists, the Spanish-American War exposed the Army as little more than a "hydra-headed holding company," a system and organization found increasingly wasteful

professional regular Army officer see Gerald Linderman, The Mirror of War: American Society and the Spanish-American War (Ann Arbor, MI: University of Michigan Press, 1974).

${ }^{132}$ Masland and Radway, Soldiers and Scholars, 4.

133 J.D. Hittle, The Military Staff: Its History and Development (Westport, CT: Greenwood Press, 1975), 201.

${ }^{134}$ James E. Hewes, From Root to McNamara: Army Organization and Administration, 1900-1963 (Washington, DC: Center of Military History, US Army, 1975), x. 
and inefficient. ${ }^{135}$ Using a modern business analogy, Root pointed out his belief that the War Department organized irrationally: "What would become of a railroad, or a steel corporation, or any great business concern if it should divide its business in that way?”136 Reflecting his experience with large corporate enterprise, he instead envisioned creating a functionally oriented and efficient body, patterned after American continental railroads, that would centrally manage the corporate army. ${ }^{137}$ With great skill and maneuvering, Root pushed a "major piece of progressive ‘efficiency’ legislation.” critically reorganized the army by means of a General Staff he convinced Congress to authorize in $1903 .{ }^{138}$

Reforms must endure to be effective. Success hinged on whether future Secretaries of War and senior army leaders continued to support rationalist reforms to modernize the army along the lines of industry during the Managerial Revolution, reforms that still inspired some active opposition. ${ }^{139}$ Root's protégé, Henry Stimson picked up the reform effort when he became Secretary of War in 1911. Stimson reinforced the principle of executive control and embarked on an ambitious program to rationalize the Army’s organization from the top down along firm military and business lines. ${ }^{140}$ Stimson seized a great opportunity by allying with Army Chief of Staff Leonard Wood, a rationalist thinker himself. ${ }^{141}$ The Stimson-Wood reforms continued to reflect principles employed by contemporary industrial managers, rationalizing and integrating previously fragmented and large-scale activities. In 1918, the army further realized the effects of

${ }^{135}$ Hewes, From Root to McNamara, 5; Hittle, The Military Staff, 195; Cockrell, "Brown Shoes and Mortar Boards,” 24-25.

${ }^{136}$ Coffman, The Regulars, 143.

${ }^{137}$ Hewes, From Root to McNamara, 369.

${ }^{138}$ Lane, “The Military Profession’s Search for Identity,” 39-42; Cockrell, "Brown Shoes and Mortar Boards,” 25-30.

${ }^{139}$ Skirbunt, "Prologue to Reform,” 165.

${ }^{140}$ Hewes, From Root to McNamara, 14.

${ }^{141}$ Skirbunt, "Prologue to Reform,” 165-166. 
the managerial revolution under Secretary of War Newton Baker and Chief of Staff General Peyton March. In less than six months, Baker, March, and associates dispensed with traditional methods and procedures by substituting rationalist principles of centralized control and decentralized operations. ${ }^{142}$ The benefits of the efforts of Root, Wood, Stimson, and earlier reformers did not become apparent until World War I and its post-bellum years, but as one historian wrote, "the story of progressive change of any type must begin long before change is accepted."143

Organizational reform was not the only avenue for transforming the Army officer management tradition. While studying Army reorganization, later military reformer and management expert Leonard Hoelscher observed that concentrating on reorganization alone might lead people away from underlying problems. If management of the Army is inefficient, merely redrawing organization charts would not solve the problem. ${ }^{144}$ Additionally, as suggested by some military historians, whenever the numbers of officers swells, a kind of Gresham's Law begins to operate, bad officers drive out the good, poor officers simply overwhelm good officers. ${ }^{145}$ Consequently, personnel reforms had to address the quality of the officers leading the

${ }^{142}$ Hewes, From Root to McNamara, 38, 49; Edward M. Coffman, “The Greatest Unsung American General of the Great War: Peyton C. March,” WorldWar1.com, accessed October 1, 2014, http://www.worldwar1.com/dbc/pcmarch.htm; See Daniel R. Beaver, Modernizing the American War Department: Change and Continuity in a Turbulent Era, 1885-1920 (Kent, OH: Kent State University Press, 2006) and Edward M. Coffman, The Hilt of the Sword: The Career of Peyton C. March (Madison, WI: University of Wisconsin Press, 1966).

${ }^{143}$ Skirbunt, "Prologue to Reform,” 166; Schifferle, “Anticipating Armageddon,” 9-12, 32; Leopold, Elihu Root, 196.

${ }^{144}$ Hewes, From Root to McNamara, 320.

145 Thomas Boccardi, "Meritocracy in the Profession of Arms," Military Review 93, no.1 (January February 2013): 22; Gabriel and Savage, Crisis in Command, 55. Gresham's law is an economic principle that applies specifically when there are two forms of commodity money in circulation that are required by legal-tender laws to be accepted as having similar face values for economic transactions. The artificially overvalued money tends to drive an artificially undervalued money out of circulation and is a consequence of price control. See Murray N. Rothbard, “Gresham's Law and Coinage,” Ludwig von Mises Institute, accessed October 1, 2014, 
reorganized large-scale Army. It was within the qualitative personnel reforms of the same period where an inflexible, managerial culture slowly implanted in the Army officer corps, an effect that would entrench over ensuing decades and prove to endure and evolve even to the present.

\section{Evaluation}

The realities of the manpower increase at the turn of the century and internal and external critical evaluations of army management made it imperative reformers focus attention on managing the quality of officer talent more efficiently. In contrast to most other countries, the American military profession was almost entirely the product of the officers themselves. Professionalism was self-induced rather than forced. ${ }^{146}$ This is not to say that American officer corps required segregation from society in order to professionalize, only that it assimilated the progressive mainstream ideas into its own culture on its own terms and at its own pace. So long as the number of officers met the imposed limits (quantity), Congress traditionally overlooked changes in promotion and talent management (quality). The rising influence of reformers whose abilities to efficiently manage systems made them "invaluable to their elite civilian counterparts in the age of organizations" catalyzed a legislative and cultural shift in the assessment of officer talent and redefined the military professional. ${ }^{147}$ One historian observed, “military professional reform paralleled precisely the early phase of the Progressive movement.” In the era of the managerial revolution, “army promotion and retirement reforms, the officer’s examination program, and the efficiency report system all fitted closely with the progressive’s drive for organization, efficiency, and the desire to provide leadership of the competent." "Business

http://mises.org/money/3s5.asp; Carl von Clausewitz, On War, eds. and trans. Michael Howard and Peter Paret (Princeton, NJ: Princeton University Press, 1976), 153. Clausewitz refers to the same phenomenon, "we have to remember that as the number of officers increases steadily in the lower ranks, the less trust that can be placed on their true insight and mature judgment."

\footnotetext{
${ }^{146}$ Huntington, The Soldier and the State, 233.

${ }^{147}$ Karsten, “Armed Progressives,” 264.
} 
progressivism,” military and civilian reform based on related beliefs, occurred simultaneously and not coincidentally. ${ }^{148}$

When it comes to reconceptualizing change or transition in a system, the role of young members or newcomers is often invaluable and necessary to energize and drive forward a new system. ${ }^{149}$ Following Upton's lead, a generation of progressive, revolutionary, or rebellious junior officers, whom historian Peter Karsten refers to as "Young Turks” in recognition of their advocating (and in some cases agitating) for reform took up the cause. ${ }^{150}$ Remarks of officers of the time reflect their views of the old system as too reliant on "superannuated individuals who have not kept pace with the march of events" who remain "tottering around in their dotage" to the embarrassment of a professionalizing army. ${ }^{151}$ Stimson remarked that the Army was "slowly awakening.” A 1911 War College graduate stated: “the battle was still on between the younger men, led by a few older officers...for a new Army and the older men who were holding fast to old ideas of organization and training... "152 Individuals such as Eben Swift, Arthur Wagner, Matthew Steele, and others sought to influence the quality of officers from the inside; to the top from the bottom. The focus of the army's lower and middle ranks turned to pursuit of specialized

${ }^{148}$ Lane, “The Military Profession’s Search for Identity,” 39-42; Gates, "The Alleged Isolation of US Army Officers in the Late 19th Century," 39; Schifferle, "Anticipating Armageddon," 8.

${ }^{149}$ Kuhn, The Structure of Scientific Revolutions, 90-91.

${ }^{150}$ Cosmas, An Army for Empire, 40; Ambrose, Upton and the Army, 3-4, 121-22, $151-$ 153; Brereton, Educating the U.S. Army, xvii; Edward L. Beach, The United States Navy: 200 Years (New York: Henry Holt and Company, 1986), 388; Stephen K. Stein, “The Greely Relief Expedition and the New Navy," International Journal of Naval History 5, no. 3 (December 2006), 7, accessed October 1, 2014. http://www.ijnhonline.org/wpcontent/uploads/2012/01/Stein_-_pdf.pdf; Karsten, “Armed Progressives,” 264. Karsten uses this term in reference to any reform-minded officers including young officers determined to modernize the Navy.

\footnotetext{
${ }^{151}$ Karsten, “Armed Progressives,” 264; Coffman, The Old Army, 230.

${ }^{152}$ Coffman, The Regulars, 184.
} 
education, certification, discrete knowledge, and status. ${ }^{153}$ The efforts of these "onward-looking officers... who tugged at the thongs of neglect and provincialism»"154 proved critical to the increasing the efficiency of the corporatizing army.

Within the span of one generation, the United States became both the leading industrialized society in the world as well as one of the leading military states. This development was parallel, if not intertwined with industrial reforms in the private sector. Root remarked that military officers were involved in "almost every branch of civil government." ${ }^{155}$ Army leader relationships with industry were more extensive than ever before. In order to coexist with its corporate counterparts, the Army adapted its system to common methods of organizing for industrialization and applied it to the career development of its officer corps, the managers for the new corporate Army organization. However, the Army did not simply borrow the best personnel practices of the civilian sector and apply them. Rather, it innovated to meet its specific organizational needs alongside its corporate civilian equivalents. Consequently, and ironically, the Army implemented a method of personnel management that would not materialize in industry for many more years. ${ }^{156}$

${ }^{153}$ Brereton, Educating the U.S. Army, xvi.
${ }^{154}$ Ganoe, The History of the United States Army, 397.
${ }^{155}$ Masland and Radway, Soldiers and Scholars, 5-6.
${ }^{156}$ Hayes, The Evolution of Military Officer Personnel Management Policies, 71, 109110. New and more scientific personnel management practices were introduced into industry from its interaction with the Army. The Army practically developed the practice of personnel appraisal and psychometrics. Industry adopted the concepts and established the precedent for the testing systems still in use. See C. C. Ling, The Management of Personnel Re1ations: History and Origins (Homewood, IL: Richard D. Irwin, Inc., 1965), 336; “Ironically, the corporate structure that emerged with the industrial age in the 19th century emulated the hierarchical military organizational structure; now it may return the favor by providing a model for military organizational change.” Andrew F. Krepinevich Jr., The Military-Technical Revolution: A Preliminary Assessment (Washington DC: Center for Strategic and Budgetary Assessments, 2002), 35. 
As the Army realized the need for more technical and managerial skills among its officers, the traditional ascriptive hierarchy transformed. ${ }^{157}$ Because traditional options for promotion were a mix of achievement and seniority, individuals such as Upton were able to circumvent the seniority system as long as their merit and achievements provided just cause. The modernizing Army focused on management, searching for maximum efficiency like industrial reformers who followed theories of Max Weber and Frederick Taylor. ${ }^{158}$ The Army consequently focused its advancements on officers who expertly and efficiently directed and administered an organization whose personnel were developing specialized skills that were becoming more and more transferable to civilian structures. This aspect was evident after the Spanish-American War when civilian-type occupational specialties began to dominate the traditional combat arms. ${ }^{159}$ To separate which officers were most effective at these practices, the Army instituted scientific assessments of their performance. By 1900, legislation passed that stipulated all officers below the grade of major take rigid examinations for promotion and mandated efficiency reports for all officers. ${ }^{160}$ The War Department reorganized the Adjutant General's Department to make it easier to eliminate the inefficient and to facilitate the selection of qualified officers for important promotions and assignments. Officers were thus required to meet newly standardized levels of efficiency and professional competence, standards that would be evaluated through a centralized bureaucracy $^{161}$

\footnotetext{
${ }^{157}$ Corona, “Career Patterns,” 129.

${ }^{158}$ For an argument of the extent of influence of Weber and Taylor's scientific management theory on military reformers, see Vandergriff, The Path to Victory, 41-44.

${ }^{159}$ See “Table 4” in Janowitz, The Professional Soldier, 65.

${ }^{160}$ Millett, Maslowski, and Feis, For the Common Defense, 248; Huntington, The Soldier and the State, 245.

${ }^{161}$ Hayes, The Evolution of Military Officer Personnel Management Policies, 70-71.
} 
The trend generally erased the traditional individualistic view of its members, seeking a streamlined standard to which all members would adapt, with some excelling above and others falling below but reinforced with the belief that it would produce absolute gains in efficiency for the organization. An officer’s competence “took on a business aspect. The soldier became primarily a worker." 162 Subjective means of determining the value of an officer and measuring his talent gave way to objective examinations, standardized evaluations, and general depreciation of character. An example of the sentiment of the time is perceptible in a 1920 lecture by General Henry Jervis:

A man could not be considered as merely a man. He was something more. He was part of machine made up of many different parts, each a man it is true, but having to play a highly specialized part. Consequently it became necessary to economize the specialized abilities of these various spare parts and assign them where their specialized abilities would do the most good. In other words, round pegs had to be selected to fill round holes. This required a careful classification of the men before assignment. ${ }^{163}$

Edward Coffman argues that mastery of technical knowledge and skills became the trademark of the professional during and after the managerial revolution. "Rather than depend upon the personal bent of individuals to...hopefully, rise to the occasion in war," the Army demanded a “systemic approach to developing leadership.”164 This “safe leadership” meant the Army could expect its officers to follow a set of well-understood methods resulting in a standardized gear for Secretary Root’s envisioned machine. ${ }^{165}$

\footnotetext{
${ }^{162}$ Ganoe, The History of the United States Army, 441.

${ }^{163}$ Department of the Army Pamphlet 20-212, History of Military Mobilization in the
} United States Army, 1775-1945 (Washington, DC: Headquarters, Department of the Army, November 1955), accessed October 1, 2014, https://archive.org/stream/PAM20-212/PAM20212_djvu.txt.

${ }^{164}$ Coffman, The Regulars, 191.

${ }^{165}$ Eben Swift, Remarks Introductory to the Course in Military Art, 1904 (Fort Leavenworth, KS, 1904), 8; Nenninger, "The Fort Leavenworth Schools," 120; Linn, The Echo of Battle, 52; Reardon, “The Study of Military History,” 3, 55-88. 
Military institutions reflect the societies that employ them. ${ }^{166}$ Paralleling the experience of society outside the military, the modest officer corps (analogous to small American communities) lost its self-sufficient and self-contained quality. Society and the military made movements toward corporate concentration and increased dependence on decisions made from a higher central authority. Men no longer discussed war in imagery of individualized character and expression; cosmopolitan thinking of the era preferred new centralized standards and congruencies rather than the provincialism that identified with decentralized or local communities. ${ }^{167}$ Progressives in uniform foremost sought efficiency and championed the need to adopt the same thinking to officer talent management. As the country and military expanded, the governing classes lost touch with and influence over Army officer development. Populist pressures to democratize the officer corps changed an intimate review of performance and potential into a routine bureaucratic matter. ${ }^{168}$ Prominent elites including business leaders, no longer in fear of a standing regular Army, sought an increase in military appropriations, application of sound management practices, and the introduction of a system of merit based promotion. ${ }^{169}$ To the new decision makers in modernizing America and its Army, older values of localism, individualism, and voluntarism were yielding to efficiency, predictability, and order. ${ }^{170}$

A clear example of a shift in values and emphasis on centralization is the coincident decline in the utility and prestige of the brevet system from the late nineteenth century through the early twentieth century. By the last quarter of the century, Congress passed laws stating that officers could not wear nor be addressed by their brevet rank, essentially reducing brevet to a vii.

${ }^{166}$ Chambers, “Conscripting for Colossus,” 299; Cohen and Gooch, Military Misfortunes,

${ }^{167}$ Linderman, “The War and the Small-Town Community,” 277, 292.

168 van Creveld, The Training of Officers, 2.

${ }^{169}$ Karsten, “Armed Progressives,” 262.

${ }^{170}$ Chambers, "Conscripting for Colossus,” 299. 
decoration with little practical purpose. By 1900, legislation passed which changed the basis of the promotion system. Promotion below the grade of brigadier general transferred to each arm, corps, or department of the Army, meaning officers could transfer without loss of rank entailed by the previous narrow limits of regimental promotion. Introduction of new awards such as the Distinguished Service Cross to recognize valorous individuals and greater legislative restriction requiring all brevet commissions to require Senate approval further negated the utility of flexible rank. By 1918, the Army discontinued all temporary promotions and provisional appointments in the Regular Army and Reserve Corps. All promotions and commissions were centrally selected, permanent, and issued in the name of the US Army only. ${ }^{171}$

Interestingly, for all its reforms, the Army could still not completely discard the concept or deny the need for rapid promotion. After essentially eliminating the method, the Army was required to brevet Tasker Bliss to full general in 1918 in order to fill the need for an additional four-star general officer, the last and highest brevet grade ever bestowed. ${ }^{172}$ Guided by various policies, regulations, and laws, the Army continued to employ temporary promotions via slightly different processes throughout the following decades in response for the need of qualified officers in specific billets, once again putting the right talent in the right position at the right time. During World War II, General George Marshall managed to convince Congress to amend legislation so that rapid promotion could once again be possible, temporarily destroying age and rank rigidity in order to advance "up and coming” officers. ${ }^{173}$ The Army commissioned several studies to examine temporary promotion. Most notably, the recommendation of a 1946 analysis advocated a hybrid centralized selection of temporary ranks and decentralized brevetting. ${ }^{174}$ Brevet rank

\footnotetext{
${ }^{171}$ Wiener, "Mex Rank Through the Ages,” 62.

172 Ibid.

173 Janowitz, The Professional Soldier, 62.

${ }^{174}$ US Army, “Appendix D.”
} 
remained authorized in Army regulations through the 1951 publication of US Army Regulation 600-15: Personnel: Rank and Precedence but it was removed entirely by $1955 .^{175}$

Assignments and Professional Development

Prior to 1900 the control of key assignments, particularly senior officer appointments, was a form of patronage which Congress and state politicians were reluctant to relinquish. The war with Spain provided several new opportunities, altering the assignment slate for the officer corps. The war afforded a larger and broader range of job experiences and duties with the acquisition of overseas territories, especially foreign military government and colonial administration. Additionally, President Roosevelt's willingness to use military power in support of national policy and objectives placed greater attention and demand on the Army and its assignment structure. ${ }^{176}$ Root's rehabilitation of Army professional schools and reorganization and establishment of the general staff created even more high-level positions. However, in keeping with Progressive thinking, these assignments in the modern Army required distinctively trained professionals. In response, Root sought and received authority in 1901 to link officer assignments to completion of military education, including the refurbished Command and General Staff School at Fort Leavenworth and the newly created Army War College.

Throughout the latter half of the nineteenth century, the Army slowly developed an elaborate and carefully integrated education system. The expansion of the education system resulted from the persistent efforts of a few creative leaders including Root and the Young Turks

\footnotetext{
${ }^{175}$ Piggott, "Promotion by Brevet," 101. As the use of brevetting in the US system declined, the British use of brevets extended beyond war-time to include peace-time advancement. By the early 1900s, a special "Brevet Board" combined the decentralized nomination and centralized selection of exceptional officers. Administratively sound and universally popular, the brevet system was enthusiastically anticipated and "had indeed become part of the texture and fabric of the Army." Unfortunately, within twenty years it too was abandoned hastily, "abolished with iconoclastic zeal in cold blood.”

${ }^{176}$ Masland and Radway, Soldiers and Scholars, 5.
} 
to push the institution past the training of combat skilled soldiers in separate arms schools to emphasize the developing professional aspects of a military career. ${ }^{177}$ The reformers regarded an integrated and combined system as a critical means to prepare the relatively small cadre of officers in peacetime for the vastly larger citizen armies they would be receiving in time of mobilization. ${ }^{178}$ The Army required officers well-educated in standard military affairs to cope with the technological, organizational, and tactical changes that occurred in the nature of warfare of the era. ${ }^{179}$ Consequently, the education system evolved to provide the competent managerial and technical professionals prerequisite for an organization comprised largely of staff officers. ${ }^{180}$ Colonel Harry Greene considered Army education as "the most important educational agency for the promotion of efficiency of the army."181

Additionally, the Army began to use its schools as a means of testing its officers and screening them for greater responsibilities. With fewer opportunities for active campaigning to distinguish themselves, ambitious officers looked to the Army schools to gain reputation and notice. ${ }^{182}$ Advancement became linked with the opportunity to attend Army schools and the degree of interaction with and influence of prestigious leaders and instructors while in attendance at those schools. ${ }^{183}$ The encouragement of the bureaucracy transformed apathy and antagonistic

\footnotetext{
${ }^{177}$ Masland and Radway, Soldiers and Scholars, 99; Skirbunt, "Prologue to Reform,” 154; William J. Webb, "The Root Reforms and Army Schools and Branches,” Center for Military History Online, May 3, 2001, accessed October 1, 2014, http://www.history.army.mil/documents/1901/Root-Schools.htm.

${ }^{178}$ Masland and Radway, Soldiers and Scholars, 96.

${ }^{179}$ Nenninger, “The Fort Leavenworth Schools,” Preface.

${ }^{180}$ Hittle, The Military Staff , 306.

${ }^{181}$ Quoted in Nenninger, “The Fort Leavenworth Schools,” 181.

${ }^{182}$ Nenninger, “The Fort Leavenworth Schools,” 85.

${ }^{183}$ Reardon, “The Study of Military History,” 6.
} 
sentiment toward Army education into action. ${ }^{184}$ Younger officers saw it as a means to advance their careers. ${ }^{185}$ Far from the egalitarian and non-parochial aims of progressive reforms, influence or connections still played a vital role for an officer's career, they were simply shifted to the Army education system. Putting regulations and ability aside, admission to the Army schools became the new and essential place to have the right friends. ${ }^{186}$

During the era, "business" became a highly prestigious occupation and the business-mind gained institutional value. By degrees, army professional education curriculum reoriented on general combined-arms training and staff work and subjects common to all officers in order to produce a standardized, conventional, and more professional officer product. Concerned with developing officers expertly trained in the science of war, the United States Military Academy narrowed the focus of its program actually moving it further from the progressive ideals of liberal education. Acknowledging future senior officers lacked required training in fields such as economics, business administration, and industrial technology, the Army created an Industrial War College to develop “specially prepared military personnel.”,187

The reformed military education system opened new paths for career advancement but engendered deep division in the officer corps. To traditionalists, the system appeared to be attracting and rewarding officers who sought the managerial path, effectively excluding and stunting the progress of outsiders and individuals unable to benefit from the new opportunities. Some directed misguided criticism toward what they viewed as a "Leavenworth mind," claiming new institutions like the school at Fort Leavenworth served only to mass-produce medium-level

\footnotetext{
${ }^{184}$ Nenninger, “The Fort Leavenworth Schools,” 91.

${ }^{185}$ Ibid., 295-296.

${ }^{186}$ Nenninger, “The Fort Leavenworth Schools,” 294-295.

${ }^{187}$ Richard Stewart, ed., American Military History, vol. 1, The United States Army and the Forging of a Nation, 1775-1917 (Washington, DC: Center of Military History, US Army, 2005), 311; Masland and Radway, Soldiers and Scholars, 86, 89-90.
} 
military technicians, staff officers, and administrators through "liberal memorizing” and rote learning over creative thinking, creating "doers rather than thinkers.”" ${ }^{188}$ They argued the Army’s prevailing concern was "the need to train staff officers in the practical matters of management,...not leav[ing] much room for a systematic study of modern land warfare.”189 Though the critique was misinformed and inaccurate, a new reality did emerge. The institution placed greater value and trust in individuals with professional military education credentials who represented a certain and predictable return, over the heroic ideal of a self-made officer capable of rising to any challenges who presented uncertain variable within the newly ordered system. ${ }^{190}$ Reflecting progressive society, Army reformers pressed to restore harmony, order, and vitality to an organization they believed was fragmented and debilitated by individual selfishness, class divisions, and parochialism. They sought to ensure the Army was standardized and smoothly running, deviating little from new expected norms. ${ }^{191}$ Remarking on the condition of the Army officer by 1911, historian William Ganoe observed,“The officer became a practical progressive in his profession, or he was cast aside." ${ }^{192}$ He added, "He cannot be promoted a single grade through his own efforts...The outlet for his energies is to be known to his superiors and

${ }^{188}$ Nenninger, “The Fort Leavenworth Schools,” 292, 312-313; Cockrell, “Brown Shoes and Mortar Boards," 41-42; van Creveld, The Training of Officers, 62, 64-65.

${ }^{189}$ Matheny, Carrying the War to the Enemy, 24.

190 "Graduates [of professional military education] had achieved a position of 'respect and separateness' in the Regular Army before 1917.” Nenninger, “The Fort Leavenworth Schools,” 344; William Geffen, "The Leavenworth Clique in World War I: A Military View," in Command and Commanders in Modern Warfare: Proceedings of the Second Military Symposium, US Air Force Academy, ed. William Geffen (Washington, DC: Government Printing Office, 1969), 52.

191 "But more than anyone...[Root] did sense the inherent stresses and strains in the modern industrial state, and he did recognize that to keep the powerful machine functioning properly judicious concessions were necessary.” Leopold, Elihu Root, 198.

${ }^{192}$ Ganoe, The History of the United States Army, 441. 
inferiors as an efficient officer." ${ }^{\text {"93 }}$ Army education played a significant role in institutionalizing and perpetuating the professionalizing process. ${ }^{194}$

Organizational scholar Edgar Schein states, “organizational cultures are created in part by leaders, and one of the most decisive functions of leadership is the creation, management, and sometimes even the destruction of culture.”195 The efforts of Root and other reformers catalyzed a massive transformation of the Army officer corps in response to the industrialized era of warfare. ${ }^{196}$ General Carter remarked, “Without [Root’s] kindly, but firm, insistence upon a reform in our military system, the Army would have carried on in the World War under the same disadvantages and discouragements that confronted it in 1898."197 Whether truly disadvantageous or not, the reforms irrevocably altered the army officer corps system from its traditional reliance on flexibility brought about by parochial and subjective assessments to a centralized, bureaucratic mechanism capable of producing efficient, predictable, and stable scientific experts and professional managers. ${ }^{198}$ The greatest change became the rigid and technical organization and management of the Army officer corps. A 1919 report of the Army personnel system states, “Thus was effected for the commissioned personnel of the Army, a centralized control...”199 Reformers observed and envied the success of nonmilitary peers who had risen more rapidly

${ }^{193}$ Ganoe, The History of the United States Army, 460-461.

${ }^{194}$ Nenninger, "The Fort Leavenworth Schools,” 344.

${ }^{195}$ Edgar H. Schein, Organizational Culture and Leadership, 2nd ed. (San Francisco, CA: Jossey-Bass, 1992), 5.

${ }^{196}$ Root's campaign for reform has been described as the "watershed of military professionalization" and the effort "that earned him his deserved reputation as one of the greatest Secretaries of War.” Bacevich, "Progressivism, Professionalism and Reform," 67; Cosmas, An Army for Empire, 322.

${ }^{197}$ Hittle, The Military Staff, 207.

${ }^{198}$ Donald. E. Vandergriff, The Path to Victory: America's Army and the Revolution in Human Affairs (Novato, CA: Presidio Press, 2002), 13.

${ }^{199}$ US Adjutant-General's Office, The Personnel System of the United States Army, vol. 1, History of the Personnel System (Washington, DC, 1919), 8. 
effectively lobbied to replace the old system with a highly regulated and rigid "up-or-out" structure. ${ }^{200}$ Over time, Congress gave the Army the system it desired. Once institutionalized, the system did not transform much over the succeeding decades of the century. ${ }^{201}$ The system failed to innovate in parallel as the industrial paradigm of warfare it had changed to contest evolved independently. ${ }^{202}$ Throughout the twentieth century, the rigid system developed to produce the managerial officer became entrenched, typified by the implementation of the 1980 Defense Officer Personnel Management Act. ${ }^{203}$ Despite the overall organizational effectiveness brought about by generations of officers who ascended by way of a rank-flexible system, the context, theory, and rationale behind the method were bound with and dismissed as an inefficient legacy of the Old Army, placed on the intellectual shelf, and consigned to irrelevance.

${ }^{200}$ Peter Karsten, “The US Citizen-Soldier's Past, Present, and Likely Future,” Parameters 31, no. 2 (Summer 2001): 70.

${ }^{201}$ John C. F. Tillson, Reducing the Impact of Tempo (Alexandria, VA: Institute for Defense Analyses, 1999), S-5; Bernabe, “Changing the Officer Promotion System,” 50; Hewes, From Root to McNamara, 370.

${ }^{202}$ Scott M. Halter, "What is an Army but the Soldiers? A Critical Assessment of the Army’s Human Capital Management System,” Military Review 92, no.1 (January-February 2012): 20; Secretary of the Army John McHugh, "Human Capital Management Reform," (Washington, DC: Headquarters, GPO, June 20, 2011); Arthur T. Coumbe, Toward a U.S. Army Officer Strategy for Success: Historical Context (Carlisle, PA: Strategic Studies Institute, September 2009), 8.

${ }^{203}$ Corona, “Career Patterns,” 129;.See Rostker et al., The Defense Officer Personnel Management Act of 1980; DOPMA set strict guidelines on how to manage officers in all services including tenure and standard rank progression and strict progression timetables. In 2010 the Defense Science Board reported DOPMA and other restrictive regulations are "inhibiting the Department's flexibility and adaptability.” Defense Science Board, Enhancing Adaptability of US Military Forces: Part A. Main Report (Washington DC: Office of the Under Secretary of Defense for Acquisition, Technology and Logistics, January 2011), 139. 


\section{Conclusion}

Tempora mutantur et nos mutamur in illis. [The times change, and we change with them] — William Harrison, Description of England, 1577

As this analysis has established, the United States Army underwent a tremendous transition in the way it administered its officers in response to institutional, cultural, and strategic conditions of the early twentieth century. ${ }^{204}$ The revolutionary change in military policy resulted from both circumstance and design. America emerged as an industrial and heterogeneous nation while its army expanded into a corporate body. Reformers desired a new army officer corps that "would be commensurate with the needs of this new colossus."205 Asserting the need for rational action, modernists sought to eliminate political behavior intrinsic to the prevailing system they believed delegitimized the increasingly critical role of managers and fostered inefficiency. ${ }^{206}$ Progressive-inspired reforms allowed the institution to adapt for the new paradigm of war it was required to confront. ${ }^{207}$ The army designed its professional officer of the twentieth century to reflect predictability, standardization, order, and efficiency.

As historian Timothy Nenninger observed, a perplexing tension emerged from the army’s attempts to transform, "produc[ing] the needed uniformity without stifling initiative was difficult." ${ }^{\text {208 }}$ Identifying solutions to problems in complex systems is difficult. Identifying the effects of implementing those responses is often just as complicated. Brian McAllister Linn cautions that the "absence of direct causation—-the ability to demonstrate that specific reform

\footnotetext{
204 "War is not conducted and military policy is not made in a vacuum. Military decisions always reflect the social and political context in which they are reached.” Cosmas, An Army for Empire, 326.

${ }^{205}$ Chambers, “Conscripting for Colossus,” 309; Cosmas, An Army for Empire, 37, 48.

${ }^{206}$ Mary Jo Hatch, Organization Theory, 2nd ed. (Oxford: Oxford University Press, 2006), 253.

${ }^{207}$ Cosmas, An Army for Empire, 326.

${ }^{208}$ Nenninger, “The Fort Leavenworth Schools,” 120.
} 
actually had the effect its planners intended—should make both officers and civilians more skeptical of the tendency of some military intellectuals to present guesses as certainties."209 Even when individuals think they are making progress, their solutions may cause more problems in the long-term, "any action may have hidden effects that cause matters to become worse and the whole strategy [being used] may be moving things in the wrong direction.”210 The institutional army began to observe expanding negative effects as the reforms became more extensive and deep-rooted, especially in the post-Industrial Era of the late-twentieth century. Army internal reports (1970, 1985, 1995) indicated an organization-wide "professional climate” reflecting the worst aspects of a managerial way of war and a promotion system that rewarded ticket punching functionaries and corporate managers over professional competence and bold, creative individuals. ${ }^{211}$ A century after the Root reforms, warnings in Army internal memos highlight the Army’s “disproportionate loss of high-potential, high-performance junior leaders.”"212 A 2011 survey of active duty general officers rated personnel management as one of the Army's weakest functions. ${ }^{213}$ Some modern army officers believe the system "has become numb to individual performance and begun to see every officer as equal." ${ }^{\text {214 }}$ Modern critics of the military bureaucracy point to a lack of innovation in the area of officer talent administration, or "human

\footnotetext{
${ }^{209}$ Linn, The Echo of Battle, 236.

${ }^{210}$ Bar-Yam, Making Things Work, 13-14.

${ }^{211}$ Linn, The Echo of Battle, 196-197, 219, 224; Gabriel and Savage, Crisis in Command, 22.

${ }^{212}$ Andrew Tilghman, “The Army’s Other Crisis: Why the Best and Brightest Young Officers are Leaving,” Washington Monthly, December 2007, accessed October 1, 2014, http://www.washingtonmonthly.com/features/2007/0712.tilghman.html.

${ }^{213}$ Volney Warner, General Officer Survey on Army Title X Activities (Washington, DC: Center for Army Analysis, 2011), originally cited in Halter, "What is an Army but Its Soldiers?," 16.

${ }^{214}$ Dave Dillege, “The Officer Critical Skills Retention Bonus,” Small Wars Journal Blog, July 18, 2007, accessed October 1, 2014, http://smallwarsjournal.com/blog/the-officercritical-skills-retention-bonus.
} 
capital management,” labeling it “parochial,” "antiquated and flawed,” and a "quagmire” that is “opaque, inflexible, dominated by seniority... and hostile to change.” ${ }^{\text {,15 }}$ External observers use terms such as "muddy boots path" and "KAFCA (Keeping the Able From Contributing to the Action)" to describe the rigid, operational focused career paths that self-reinforce to keep the system intact rather than award creativity and ascendant talent. ${ }^{216}$ Former Secretary of Defense Robert Gates regrets that the characteristics required of an officer in war seem to be considered incompatible with those deemed essential for career success in peace. ${ }^{217}$ A century after the reforms, critics still decry the negative aspects of seniority and "political patronage of a bygone era” that still exist in the management of the Army officer corps. ${ }^{218}$

Some contend the effect of professional reforms has created a deepening "persistent dilemma.” In the Industrial Age, the conception of the officer as a heroic leader began to change

${ }^{215}$ Halter, "What is an Army but the Soldiers?," 16; Boccardi, “Meritocracy,” 22; Kane, Bleeding Talent, 7. Also see Aaron MacLean, “We Don’t Reward Top Military Performers—and It's Costing Us,” The Washington Post, November 9, 2011, accessed October 1, 2014, http://www.washingtonpost.com/national/on-leadership/we-dont-reward-top-militaryperformersand-its-costing-us/2011/11/09/gIQApzbj5M_story.html.

${ }^{216}$ Leonard L. Lira, "Transformation and the Evolution of the Professional Military Ethic: A Current Assessment,” in Mark H. Wiggins and Larry Dabeck, eds., Exploring the Professional Military Ethic (Symposium Report, United States Army Command and General Staff College, 2010), 229; Arthur Hadley. The Straw Giant: Triumph and Failure, America's Armed Forces: A Report from the Field (New York: Random House, 1986), 22; "The lack of flexibility in the system undermines the strategic objectives of the [Army Leader Development Strategy].” Christopher T. Drew, "Limitations for a Successful Army Leader Development Strategy” (SAMS Monograph, United States Army Command and General Staff College, 2013), 24; Charles D. Allen, "Beyond Leading Boots on the Ground," The Washington Post, November 2011, accessed October 1, 2014, http://www.washingtonpost.com/national/on-leadership/thesenior-military-leaders-we-need/2011/11/09/gIQABZQj5M_story.html.

${ }^{217}$ Robert M. Gates, Duty: Memoirs of a Secretary at War (New York: Alfred A. Knopf, 2014), 577.

${ }^{218}$ For an example critical of modern political patronage, see the USA Today’s Editorial Board article, "Update Military Academy Nominations: Our View,” USA Today, September 21, 2014, accessed October 1, 2014, http://www.usatoday.com/story/opinion/2014/09/21/militaryacademy-education-congress-nominations-editorials-debates/16015003/. 
to that of a military manager. ${ }^{219}$ Echoing this sentiment, Historians Eliot Cohen and John Gooch observe, "For the modern commander is much more akin to the managing director of a large conglomerate enterprise than he ever is to the warrior chief of old. He has become the head of a complex military organization...”220 Gates observes, “too many officers were assigned...because [they were] identified as 'next in line' rather than because they were selected as best qualified” while "too many talented officers who achieved real...success were rotated...simply to keep the personnel system running smoothly."221 The profession's need to recruit and retain officers skilled in military management for its elite while the officers must simultaneously be able to perpetuate the traditions of a heroic leader creates tension and makes it difficult to imbue and reward the fighter spirit in the next generations of officers. The proclivity toward seeking scientific management and linear thought to confront the uncertainty of war in the hypertechnological environment conflicts with conventional heroic ideals and matters of personal honor. ${ }^{222}$ This has led some to claim the traditional character is lost, "the identity of the 'soldierwarrior’ has become obsolete."223

The emergence of the progressive view of military professionalism at the turn of the twentieth-century left a lasting impression that military genius was superfluous, if not hazardous. It was "the end of the era of the so-called 'military genius' whose individualism and

${ }^{219}$ Geffen, "Introduction,” 4; Nenninger, “The Fort Leavenworth Schools,” 3; Huntington, The Soldier and the State, 256; Weigley, "The Elihu Root Reforms and the Progressive Era,” 11; Janowitz, The Professional Soldier, 20-21.

${ }^{220}$ Cohen and Gooch, Military Misfortunes, 7.

${ }^{221}$ Gates, Duty, 577.

${ }^{222}$ Morris Janowitz, The New Military (New York: Russel Sage Foundation, 1964), 1718; Gabriel and Savage, Crisis in Command, 23.

${ }^{223}$ Janowitz, The Professional Soldier, 35, 72-73; Elliott Abrams and Andrew J. Bacevich, “A Symposium on Citizenship and Military Service,” Parameters 31, no. 2 (Summer 2001): 20. 
unpredictability became an anathema., 224 Skeptical of military genius, the army required its officers to be perfected machines of technical skill and tactical ability, not brilliant individuals. War essentially became an industrial process directed by a trained corporate elite. ${ }^{225}$ In 1907 , students at Fort Leavenworth were advised, "In any office in the military service, search should be made nowadays, not for a brilliant soldier, not for a genius, but for one that knows thoroughly the duties of the office.”226 The German system, so influential but misinterpreted by many American Army reformers of the time, was sincerely but erroneously praised as the "triumph of organized mediocrity," the personification of whittling all officers into similar cogs of machine where "the efficiency of every part is constantly developed, but subordinated always to the efficiency of the whole.”227 The Army intentionally constructed its professional officers to be scientific experts and professional managers within an inflexible and bureaucratic system in the search for unequivocal efficiency and order. ${ }^{228}$ The satire of Gilbert and Sullivan's “MajorGeneral” perverted into an idealized character of the modern military leader. ${ }^{229}$ Individuals

\footnotetext{
${ }^{224}$ Reardon, “The Study of Military History,” 3.

${ }^{225}$ Geffen, “Introduction,” 4; Nenninger, “The Fort Leavenworth Schools,” 120; Linn,
} The Echo of Battle, 100.

${ }^{226}$ Steele, “The Conduct of War," 26.

${ }^{227}$ Huntington, The Soldier and the State, 257; Weigley, "The Elihu Root Reforms and the Progressive Era,” 18-19.

${ }^{228}$ Weigley, “The Elihu Root Reforms and the Progressive Era,” 21. One author claims this linear thought "evolved out the Industrial-age way of war...centers on the rote memorization of process, or what is today called the Military Decision Making Process (MDMP). MDMP evolved from a scientific way to organize thoughts in the preparation and execution of missions...The MDMP was created by U.S. Army Major Eben Swift in 1897. At the time of the emergence of the philosophy of scientific management based on the theories of Frederick Taylor, Swift's methods were seen as the basis for a professional military education." See Donald E. Vandergriff, "Military Education - We Are Stuck in the Past," Military.com: Military Opinions, January 13, 2005, accessed October 1, 2014, http://www.military.com/Opinions/1,14790,Vandergriff_011305-P1,00.html.

${ }^{229}$ The song, performed in the 1879 Gilbert and Sullivan comic opera The Pirates of Penzance, is intended to be a caricature of the ideal, "modern" educated British Army officer. Though a parody of the mock-heroic, it does not imply that British generals were inept. The 
displaying ascendant talent represented destabilizing agents because their talents would overflow the niches allocated to them in the organized structure and system. It is difficult to imagine an individual such as John J. Pershing or Dwight D. Eisenhower rising to the highest ranks under the lock-step process and strict limitations of the new American system. The age of trusting in "great captains” had passed, the “composite mind” was paramount for modern war. ${ }^{230}$

The lack of agility in the officer ranks stemming from the professional reforms persists in the present army system because it is an inheritance. Military personnel policy is "a "legacy system built on a legacy system built on a legacy system." ${ }^{231}$ In 2011, Gates admitted in a speech at the United States Military Academy that his greatest worry was how the army could "break up the institutional concrete, its bureaucratic rigidity in its assignments and promotion processes in order to retain, challenge, and inspire its best, brightest, and most battle-tested young officers to lead the service in the future?”232 In order to transcend the present crisis, a senior leader like Gates "must be willing to entertain the possibility of large flaws in how his organization operates, and be willing to risk much to correct them." ${ }^{233}$ Without correction, the reformed officer corps management system of the twentieth (or twenty-first) century will generally continue to suppress aptitude and ability like that displayed by Emory Upton. The system has adopted a bureaucratic

comic-point is that despite a vast education, his reliance on rote memorization of historical and scientific facts leave him unprepared for and unable to adapt to modern warfare. See Gayden Wren, A Most Ingenious Paradox: The Art of Gilbert and Sullivan (New York: Oxford University Press, 2001), 86, 110.

${ }^{230}$ Linn, The Echo of Battle, 141.

${ }^{231}$ Vandergriff, The Path to Victory, 3; Bernabe, “Changing the Officer Promotion System,” 57-59; Kane, Bleeding Talent, 110-111. Kane asserts that military talent management has become excessively complex because of "path dependence", it is fundamentally a legacy system, something implemented in a previous era.

${ }^{232}$ US Department of Defense. “Secretary of Defense Speech,” February 25, 2011, accessed October 1, 2014, http://www.defense.gov/speeches/speech.aspx?speechid=1539.

233 "We must not be afraid to tell our nation that the way we select, develop and commission our officers is out of date, based on assumptions made a hundred years ago." Vandergriff, “Military Education”; Cohen and Gooch, Military Misfortunes, 244. 
process focused on predictive selection and advancement of effective managers rather than rapid and effective placement and use of ascendant talent. ${ }^{234}$ This “technical extension of bureaucracy," organizational theorist Donald Schon asserts,

...reinforces the confinement of professional work to precisely defined channels of expertise, exacerbates the inherent conflict between bureaucracy and professional identity. Within highly specialized, technically administered systems of bureaucratic control, how can professionals think of themselves as autonomous practitioners?”235

The search for the "optimum mix of qualities and attributes that make the ideal commander" and attempting to recreate them in assembly-line fashion seems to have brought the Army around fullcircle as it once again faces an exigency in regard to officer talent management. ${ }^{236}$

In 1957, Samuel Huntington, who produced the first academic attempt at identifying the unique elements of military professionalism, observed that the "military mind" of the professional soldier is frequently characterized as mediocre in intelligence, range, and imagination. He goes further in claiming military and civilian writers generally agree that the military mind is “disciplined, rigid, logical, scientific; it is not flexible, tolerant, intuitive, emotional.”237 To claim the army's personnel problems are due to the grouping of like-minded individuals over-simplifies the issue. ${ }^{238}$ Huntington is closer to the point when he notes this perception is variously attributed to "the organization of the military profession which discourages intellectual initiative" and "the infrequent opportunities which an officer has actively to apply his skill.” ${ }^{239}$ The army’s system

${ }^{234}$ Barrett K. Peavie, Retaining Talent for Army 2020: Overcoming Institutional Barriers (Carlisle, PA: US Army War College, March 2012), 8-9.

${ }^{235}$ Donald A. Schon, The Reflective Practitioner: How Professionals Think in Action (New York: Basic Books, 1983), 337.

${ }^{236}$ Cohen and Gooch, Military Misfortunes, 242.

${ }^{237}$ Huntington, The Soldier and the State, 60.

${ }^{238}$ For an explanation debunking the "military mind" as a simple explanatory cause for military problems, see Cohen and Gooch, Military Misfortunes, 10-14.

${ }^{239}$ Huntington, The Soldier and the State, 59; See Lloyd J. Matthews, “The Uniformed Intellectual and His Place in American Arms,” Army 52, no.7 (July/August 2002). 
of generating, crafting, self-selecting, and assigning officers leads to the emergent behavior described by Huntington and criticized by other modern observers. This "homosocial reproduction,” may reinforce a culture where innovative, boundary spanning, risk-taking, leadership necessary to guarantee the adaptability of the profession may not be supported. ${ }^{240}$ If this is true, the reforms instituted at the turn of the twentieth century had the effect the institution desired, fulfilling Upton's paradox. ${ }^{241}$ The army set a fixed course for its officer talent management that not only prepared it for its next war, but guided it, for better or for worse, through the remainder of the century and on into the next. ${ }^{242}$ As German philosopher Jurgen Habermas predicted, the institution (and modern society) developed, and have become governed by, scientific, technical, and administrative experts who focus on the technically-efficient and rational way of achieving goals. ${ }^{243}$ The appropriateness of that military mind to contemporary warfare is another issue entirely, and is at the heart of much of the criticism of modern officer talent management.

${ }^{240}$ Pierce, Organizational Culture, 17. Homosocial reproduction is process whereby those who are selected and prepared to eventually become future leaders of the Army tend to reflect the patterns of existing leaders and therefore foster a perpetuation of existing values and culture. For more on this circular logic, see Joanne Martin, Organizational Culture: Mapping the Terrain (Thousand Oaks, CA: Sage Publications, 2002) and Christopher Paparone, “Deconstructing Army Leadership,” Military Review 84, no. 1 (January-February 2004), accessed October 1, 2014, http://www.army.mil/professionalWriting/volumes/volume2/march_2004/3_04_4_pf.html.

${ }^{241}$ For an excellent analysis of the effects of placing increasing emphasis on bureaucratic values during the twentieth century, see Andrew J. Bacevich, Jr., "Progressivism, Professionalism and Reform,” Parameters 9, no. 1 (1979): 66-71.

242 "Unfortunately, remnants of the century-old [talent] employment culture remain in the Army today, restricting its ability to effectively employ officers.” Casey Wardynski, David S. Lyle, and Michael J. Colarusso, Towards a US Army Officer Strategy for Success: Employing Talent (Carlisle, PA: Strategic Studies Institute, May 2010), 7.

${ }^{243}$ Jurgen Habermas, Toward a Rational Society (London: Heineman, 1971), cited in Hatch, Organizational Theory, 268-269. 
Interestingly, residual traces of the old system remain, most notably the relative rank flexibility that exists within the general officer ranks. The smaller population, focus on general skills and aptitude, limited constraints, and the more personal knowledge of the character and personal attributes of this cohort of officers lends itself to a more decentralized and optimizing process analogous to that used by the Old Army. The system is based on army-internal boards that recommend individuals to the President for general officer promotion. When vacancies occur (through promotion or retirement), the President—with counsel from the Secretary of Defense, Secretary of the Army, and the Army Chief of Staff—nominates officers from these lists and the Senate confirms or refutes the nomination. The transparent design of the system effectively and efficiently identifies and places the right officers in the jobs that require and match their specific capabilities and competence. Modern reformers may consider why such a successful process cannot be replicated throughout the system, and why such a model is not adapted to lower echelons within the institution. ${ }^{244}$

Writing of military matters, Carl von Clausewitz noted, “criticism exists only to recognize the truth, not to act as judge. ${ }^{\text {245 }}$ The purpose of this analysis is not to form opinion on the decisions and events of a bygone era, only to observe and investigate the proximate and longterm effects of the transformation. Whenever one probes the relation of the military to society, one tends to uncover new links and overlays, indications that for all its unique structures and missions, the American military is still the product of greater society. ${ }^{246}$ Linn argues that one of the Army's enduring myths is that its great reforms, like those initiated in the Progressive Era,

\footnotetext{
${ }^{244}$ Vandergriff, The Path to Victory, 19. Any such effort to change modern systems should note Vandergriff's argument that the term reform "carries a tremendous amount of emotional baggage" and reforms "must be revolutionary in thought and total in action."

${ }^{245}$ Quoted in Peter Paret, Clausewitz and the State (New York: Oxford University Press, 1976), 341.

${ }^{246}$ Gabriel and Savage, Crisis in Command, 24.
} 
were entirely self-generated without the influence of society and that its transformative initiatives actually prepared it for the wars it would fight. ${ }^{247}$ More accurately, the twentieth century army adapted its culture and organization to reflect society’s views of modernity, equity, and efficiency. ${ }^{248}$ However, something must change if an organization's culture eventually prevents it from developing its leaders to be capable of adapting and flexibly responding to its current setting, particularly the volatile, uncertain, complex, and ambiguous environment army officers confront today. ${ }^{249}$ Over two decades ago, the authors of a study on the officer personnel management system recommended,

...consider the need for fundamental changes in the way officers will be managed in the new century. Any new officer management legislation should not be based on how serving officers are used to being managed or as a reaction to past practices and outdated situations, but on how future officers will need to be managed to maintain requisite quantity and quality to confront the dynamics of the future environment.,250

At the turn of the twenty-first century, military historian Peter Karsten reached the same conclusion, “....it is time to initiate a radical rethinking and reworking of the system of officer promotions," and the point has continued to draw increased consideration over the past decade. ${ }^{251}$ The army may be overdue for reform of its officer management system to reflect postmodern views on talent management and organizational efficiency. ${ }^{252}$

${ }^{247}$ Linn, The Echo of Battle, 236.

${ }^{248}$ Peter Karsten, introduction to The Military in America: From the Colonial Era to the Present, ed. Peter Karsten (New York: Free Press, 1980), 18.

${ }^{249}$ Pierce, Organizational Culture, 18; Schein, Organizational Culture and Leadership.

${ }^{250}$ Rostker, et al., The Defense Officer Personnel Management Act of 1980, 70.

${ }^{251}$ Karsten, “The US Citizen-Soldier’s Past, Present, and Likely Future,” 70.

252 The army is taking an active and thoughtful approach to analyzing officer talent management, especially at the Office of Economic and Manpower Analysis at the United States Military Academy. In particular, see the series of six monographs of Towards a US Army Officer Strategy for Success by Casey Wardynski, David S. Lyle, and Michael J. Colarusso; The term "postmodern" coincides generally with the era of the all-volunteer force and the institution-tooccupation debate among military observers. See Charles Moskos, "What Ails the All-volunteer Force: An Institutional Perspective,” Parameters 31, no. 2 (Summer 2001): 29-31. 
If "modern war -like modern life-- is a complex business," the army should anchor thinking of its personnel system as complex and adaptive, a contemporary approach that does not necessarily require originality. ${ }^{253}$ An analysis of history reveals the Old Army instinctively recognized what modern systems theory explains, if "autonomy is distributed across many system components, its behavior may be qualitatively different to the centralized model...a system with distributed control may be expected to be less efficient but more robust and adaptive.”254 Examination of the past shows the old system acknowledged and adjusted for what modern cultural research affirms: US Army officers are products of a timeless national culture that embraces specific traits. ${ }^{255}$ When researching the past for better understanding of the future, one should notice that out-of-date concepts are not in principle irrational just because they were previously discarded. ${ }^{256}$ By studying its history, the army can discover (or rediscover) the value in “small, well focused actions,” how mechanisms like brevetting or temporary promotion “can sometimes produce significant, enduring improvements, if they're in the right place.”257

Thomas Ricks observed, “Amateurs talk tactics, professionals talk logistics, and people who know what they are talking about talk personnel policy."258 Army leaders today—like Upton,

${ }^{253}$ Cohen and Gooch, Military Misfortunes, 23; Hewes, From Root to McNamara, 374.

${ }^{254}$ Alex J. Ryan, “What is a Systems Approach?” Cornell University Library, September 10, 2008, 30, accessed October 1, 2014, http://arxiv.org/pdf/0809.1698.pdf.

${ }^{255}$ The influential traits are as follows: hierarchy is only necessary for expediency because superiors are expected to consult with subordinates, innovative ideas or deviant behavior are more acceptable than rules and regulations, individual liberty is paramount, and assertiveness, decisiveness, and self-promotion are valued. Dutch theorist Geert Hofstede categorized these US culture traits as low power distance index, weak uncertainty avoidance, individualistic, and masculine; See Hatch, Organization Theory, 181-185.

${ }^{256}$ Kuhn, The Structure of Scientific Revolutions, 3; Karsten, “The US Citizen-Soldier’s Past, Present, and Likely Future,” 69-70. Karsten proposes such a rediscovery, a return to the "earlier and better promotion policy" of the $19^{\text {th }}$ century.

${ }^{257}$ Peter Senge, The Fifth Discipline, 64.

258 Thomas E. Ricks, “The Army and Post-9/11 Change,” The Best Defense (blog), ForeignPolicy.com, November 17, 2010, accessed October 1, 2014, 
Root and the reformers over a century ago-face a clear personnel policy challenge, a situation that presents a vital opportunity to reform in order to confront an evolving paradigm of conflict. The Army of the early twenty first century will be better adapted to confront the complexity of modern warfare if it chooses to take bold action, but it does not have to approach the problem blind and uninformed. The army can effectively prepare for the future by thoughtfully revisiting its past.

http://ricks.foreignpolicy.com/posts/2010/11/17/the_army_and_post_911_change. Ricks received the 2000 Pulitzer Prize for National Reporting (as part of the Wall Street Journal team) for articles on how the US military might adapt to meet twenty-first-century demands. 


\section{Bibliography}

“Augustus Gabriel Tassin.” Arlington National Cemetery Website. May 13, 2006. Accessed October 1, 2014. http://www.arlingtoncemetery.net/agtassin.htm.

Abrams, Elliott and Andrew J. Bacevich. “A Symposium on Citizenship and Military Service.” Parameters 31, no. 2 (Summer 2001): 18-22.

Allen, Charles D. "Beyond Leading Boots on the Ground.” The Washington Post. November 2011. Accessed October 1, 2014. http://www.washingtonpost.com/national/onleadership/the-senior-military-leaders-we-need/2011/11/09/gIQABZQj5M_story.html.

Ambrose, Stephen E. Upton and the Army. Baton Rouge, LA: Louisiana State University Press, 1964.

Bacevich, Andrew J., Jr. “Progressivism, Professionalism and Reform.” Parameters 9, no. 1 (1979): 66-71.

Bar-Yam, Yaneer. Making Things Work: Solving Complex Problems in a Complex World. Cambridge, MA: NECSI, Knowledge Press, 2004.

Beach, Edward L. The United States Navy: 200 Years. New York: Henry Holt and Company, 1986.

Beaver, Daniel R. Modernizing the American War Department: Change and Continuity in a Turbulent Era, 1885-1920. Kent, OH: Kent State University Press, 2006.

Beers, F.W., ed. Our County and Its People: A Descriptive Work on Genesee County, New York. J.W. Vose \& Co., Publishers, Syracuse, N. Y. 1890. Accessed October 1, 2014. http://www.onlinebiographies.info/ny/genesee/upton-e.htm.

Bernabe, Sean C. "Changing the Officer Promotion System to Support Unit Focused Stability (UFS).” SAMS Monograph. United States Army Command and General Staff College, 2005.

Boccardi ,Thomas. "Meritocracy in the Profession of Arms.” Military Review 93, no.1 (January February 2013): 17-23.

Bonura, Michael A. Under the Shadow of Napoleon: French Influence on the American Way of Warfare from the War of 1812 to the Outbreak of WWII. New York: New York University Press, 2012.

Brereton Todd R. Educating the U.S. Army: Arthur Wagner and Reform, 1875-1905. Lincoln, NE: University of Nebraska Press, 2000.

Builder, Carl H. The Masks of War: American Military Styles in Strategy and Analysis. Baltimore, MD: Johns Hopkins University Press, 1989.

Carter, William H. The American Army. Indianapolis, IN: The Bobbs-Merrill Company, 1915. 
Cassidy, Robert. "Prophets or Praetorians? The Uptonian Paradox and the Powell Corollary." Parameters 33, no. 3 (September 2003): 130-143.

Chambers, John W. II. "Conscripting for Colossus: The Progressive Era and the Origin of the Modern Military Draft in the United States in World War I.” In The Military in America: From the Colonial Era to the Present, edited by Peter Karsten. New York: Free Press, 1980 .

Clausewitz, Carl von. On War. Edited and translated by Michael Howard and Peter Paret. Princeton, NJ: Princeton University Press, 1976.

Cockrell, Philip C. "Brown Shoes and Mortar Boards: US Army Professional Education at the Command and General Staff School Fort Leavenworth, Kansas, 1919-1940.” PhD diss., University of South Carolina, 1991.

Coffman, Edward M. "The Greatest Unsung American General of the Great War: Peyton C. March.” WorldWar1.com. Accessed October 1, 2014. http://www.worldwar1.com/dbc/pcmarch.htm.

- The Hilt of the Sword: The Career of Peyton C. March. Madison, WI: University of Wisconsin Press, 1966.

_. "The Long Shadow of The Soldier and the State.” Journal of Military History 55, no. 1 (January 1991): 69-82.

- The Old Army: A Portrait of the American Army in Peacetime, 1784-1898. New York: Oxford University Press, 1986.

- The Regulars: The American Army, 1898-1941. Cambridge, MA: Belknap Press of Harvard University Press, 2004.

Cohen, Eliot A. and John Gooch. Military Misfortunes: The Anatomy of Failure in War. New York: Free Press, 1990.

Corona, Victor P. “Career Patterns in the U.S. Army Officer Corps.” Public Organization Review 11, no. 2 (2011): 109-134.

Cosmas, Graham A. An Army for Empire: The United States Army in the Spanish-American War. College Station, TX: Texas A\&M University Press, 1998.

Coumbe, Arthur T. Toward a U.S. Army Officer Strategy for Success: Historical Context. Carlisle, PA: Strategic Studies Institute, September 2009.

Creveld, Martin van. The Training of Officers: From Military Professionalism to Irrelevance. New York: Free Press, 1990.

Curtis, W.A. “True Stories of Army Life.” The Era Magazine 15, (January-June 1905): 49-53. 
Defense Science Board. Enhancing Adaptability of US Military Forces: Part A. Main Report. Washington DC: Office of the Under Secretary of Defense for Acquisition, Technology and Logistics, January 2011.

Department of the Army Pamphlet 20-212, History of Military Mobilization in the United States Army, 1775-1945. Washington, DC: Headquarters, Department of the Army, November 1955. Accessed October 1, 2014. https://archive.org/stream/PAM20-212/PAM20212_djvu.txt.

Department of the Army Pamphlet 600-3, Commissioned Officer Professional Development and Career Management. Washington, DC: Headquarters, Department of the Army, February 2010.

Department of the Army Pamphlet 600-65, Leadership Statements and Quotes. Washington, DC: Headquarters, Department of the Army, November 1985.

Dillege, Dave, “The Officer Critical Skills Retention Bonus.” Small Wars Journal Blog. July 18, 2007. Accessed October 1, 2014. http://smallwarsjournal.com/blog/the-officer-criticalskills-retention-bonus.

Drew, Christopher T. "Limitations for a Successful Army Leader Development Strategy." SAMS Monograph, United States Army Command and General Staff College, 2013.

Eicher John H. and David J. Eicher. Civil War High Commands. Stanford, CA: Stanford University Press, 2001.

“Fredrick Funston Papers: Collection 33.” Kansas Historical Society. Accessed October 1, 2014. http://www.kshs.org/p/frederick-funston-papers/14027.

Gabriel, Richard A. and Paul L. Savage. Crisis in Command: Mismanagement in the Army. New York: Hill and Wang, 1978.

Gaddis, John L. The Landscape of History: How Historians Map the Past. New York: Oxford University Press, 2002.

Ganoe, William A. The History of the United States Army, Rev. ed. Ashton, MD: Eric Lundberg, 1964.

Gates, John M. "The Alleged Isolation of US Army Officers in the Late 19th Century." Parameters 10, (Spring 1980): 32-45.

- Schoolbooks and Krags: The United States Army in the Philippines, 18981902. Westport, CT: Greenwood Press, 1973.

Gates, Robert M. Duty: Memoirs of a Secretary at War. New York: Alfred A. Knopf, 2014.

Geffen, William, ed. Command and Commanders in Modern Warfare: Proceedings of the Second Military Symposium, US Air Force Academy. Washington, DC: Government Printing Office, 1969. 
- “The Leavenworth Clique in World War I: A Military View.” In Command and Commanders in Modern Warfare: Proceedings of the Second Military Symposium, US Air Force Academy, edited by William Geffen. Washington, DC: Government Printing Office, 1969.

“Guy Vernor Henry, Jr.” Arlington National Cemetery Website. November 11, 2007. Accessed October 1, 2014. http://www.arlingtoncemetery.net/ghenryjr.htm.

Habermas, Jurgen. Toward a Rational Society. London: Heineman, 1971.

Hadley, Arthur. The Straw Giant: Triumph and Failure, America's Armed Forces: A Report from the Field. New York: Random House, 1986.

Halter, Scott M. "What is an Army but the Soldiers? A Critical Assessment of the Army's Human Capital Management System.” Military Review 92, no.1 (January-February 2012): 16-23.

Hargreaves, Reginald. “Ladder to the Stars.” Army 20, (September 1970): 42-48.

Hatch, Mary Jo. Organization Theory, 2nd ed. Oxford: Oxford University Press, 2006.

Hayes, James E. The Evolution of Military Officer Personnel Management Policies: A Preliminary Study with Parallels from Industry. Santa Monica, CA: RAND, 1975.

Henry, Guy V. Jr. “A Brief Narrative of the Life of Guy V. Henry Jr.” Carlisle, PA: US Army Military History Institute, 1965.

Head, Charles O. The Art of Generalship. Aldershot, England: Gale \& Polden, 1930.

Hewes, James E. From Root to McNamara: Army Organization and Administration, 1900-1963. Washington, DC: Center of Military History, US Army, 1975.

Hittle, J.D. The Military Staff: Its History and Development. Westport, CT: Greenwood Press, 1975.

Huntington, Samuel P. The Soldier and the State; The Theory and Politics of Civil-Military Relations. Cambridge, MA: Belknap Press of Harvard University Press, 1957.

Janowitz, Morris. The New Military. New York: Russel Sage Foundation, 1964.

—. The Professional Soldier. New York: Free Press, 1971.

Kane, Timothy J. Bleeding Talent: How the US Military Mismanages Great Leaders and Why It's Time for a Revolution. New York: Palgrave Macmillan, 2012.

Karsten, Peter. “Armed Progressives: The Military Reorganizes for the American Century.” In The Military in America: From the Colonial Era to the Present, edited by Peter Karsten. New York: Free Press, 1986.

-, ed. The Military in America: From the Colonial Era to the Present. New York: Free Press, 1986. 
—. "The US Citizen-Soldier's Past, Present, and Likely Future.” Parameters 31, no. 2 (Summer 2001): 61-73.

Kennedy, Robert C. “Who Is This Criminal?” HarpWeek. 2001. Accessed October 1, 2014. http://www.nytimes.com/learning/general/onthisday/harp/0813.html.

Krepinevich, Andrew F. Jr. The Military-Technical Revolution: A Preliminary Assessment. Washington DC: Center for Strategic and Budgetary Assessments, 2002.

Kuhn, Thomas S. The Structure of Scientific Revolutions. Chicago, IL: University of Chicago Press, 1970.

Lane, Jack C. “The Military Profession’s Search for Identity.” Marine Corps Gazette, 57, no. 6 (June 1973): 36-42.

Lee, Mordecai. Bureaus of Efficiency: Reforming Local Government in the Progressive Era. Milwaukee, WI: Marquette University Press, 2008.

Lenney, John J. Rankers: The Odyssey of the Enlisted Regular Soldier of America and Britain. New York: Greenburg, 1950.

Leopold, Richard W. Elihu Root and the Conservative Tradition. Boston: Little, Brown, 1954.

Linderman, Gerald F. The Mirror of War: American Society and the Spanish-American War. Ann Arbor, MI: University of Michigan Press, 1974.

_. "The Spanish-American War and the Small-Town Community." In The Military in America: From the Colonial Era to the Present, edited by Peter Karsten. New York: Free Press, 1980.

Ling, C. C. The Management of Personnel Re1ations: History and Origins. Homewood, IL: Richard D. Irwin, Inc., 1965.

Linn, Brian McAllister. The Echo of Battle: The Army's Way of War. Cambridge, MA: Harvard University Press, 2007.

Lira, Leonard L. "Transformation and the Evolution of the Professional Military Ethic: A Current Assessment.” In Exploring the Professional Military Ethic, edited by Mark H. Wiggins and Larry Dabeck. Symposium Report, United States Army Command and General Staff College, 2010.

Livesey, Ruth. "Fin de Siècle.” Oxford Bibliographies. Accessed October 1, 2014. http://www.oxfordbibliographies.com/view/document/obo-9780199799558/obo9780199799558-0030.xml.

Lodge, Henry Cabot. “The Spanish-American War.” Harpers New Monthly Magazine 98, no. 586 (May 1899): 505-523.

MacLean, Aaron. “We Don’t Reward Top Military Performers—and It’s Costing Us.” The Washington Post. November 9, 2011. Accessed October 1, 2014. 
http://www.washingtonpost.com/national/on-leadership/we-dont-reward-top-militaryperformersand-its-costing-us/2011/11/09/gIQApzbj5M_story.html.

Magruder, John H. III. "The Brevet in the Marine Corps." Marine Corps Gazette 39, no.11 (November 1955). Accessed October 1, 2014. https://www.mcamarines.org/gazette/1955/11/brevet-marine-corps.

“Major General Leonard Wood.” In Biographical Sketches of Distinguished Officers of the Army and Navy. New York: L.R. Hamersly, 1905.

Martin, Joanne. Organizational Culture: Mapping the Terrain. Thousand Oaks, CA: Sage Publications, 2002.

Masland, John and Laurence Radway. Soldiers and Scholars: Military Education and National Policy. Princeton, NJ: Princeton University Press, 1957.

Matheny, Michael R. Carrying the War to the Enemy: American Operational Art to 1945. Norman, OK: University of Oklahoma Press, 2011.

Matthews, Lloyd J. “The Uniformed Intellectual and His Place in American Arms.” Army 52, no.7 (July/August 2002): 17-25.

McHugh, John. "Human Capital Management Reform.” Washington, DC: Headquarters, GPO, June 20, 2011.

Merritt, Wesley. “The Army of the United States” in The Armies of Today: A Description of the Armies of the Leading Nations at the Present Time. New York: Harper \& Brothers, 1893.

Millett, Allan Reed, Peter Maslowski, and William B. Feis. For the Common Defense: A Military History of the United States from 1607 to 2012, 3rd ed. New York: Free Press, 2012.

Millis, Walter. Arms and Men: A Study in American Military History. New York: G.P. Putnam’s Sons, 1956.

Mills, C. Wright. The Power Elite. New York: Oxford University Press, 1956.

Moskos, Charles. "What Ails the All-volunteer Force: An Institutional Perspective.” Parameters 31, no. 2 (Summer 2001): 29-47.

Nenninger, Timothy K. “The Fort Leavenworth Schools: Post-Graduate Military Education and Professionalization in the US Army, 1880-1920.” PhD diss., University of Wisconsin, 1974.

Paparone, Christopher. “Deconstructing Army Leadership.” Military Review 84, no. 1 (JanuaryFebruary 2004). Accessed October 1, 2014. http://www.army.mil/professionalWriting/volumes/volume2/march_2004/3_04_4_pf.htm 1 .

Paret, Peter. Clausewitz and the State. New York: Oxford University Press, 1976. 
Peavie, Barrett K. Retaining Talent for Army 2020: Overcoming Institutional Barriers. Carlisle, PA: US Army War College, March 2012.

Pershing, John J. My Life Before the World War, 1860-1917. Edited by John T. Greenwood. Lexington, KY: University Press of Kentucky, 2013.

Pierce, James G. Is the Organizational Culture of the US Army Congruent with the Professional Development of Its Senior Level Officer Corps?. Carlisle, PA: Strategic Studies Institute, September 2010.

Piggott, F.S.G. “Promotion by Brevet.” Army Quarterly 59, (October 1949): 97-104.

Rand, Heinz P. “Bring Back the Brevet.” Army 9, (September 1958): 50-53.

Reardon, Carol A. "The Study of Military History and the Growth of Professionalism in the US Army Before World War I.” PhD diss., University of Kentucky, 1987.

Ricks, Thomas E. “The Army and Post-9/11 Change.” The Best Defense, ForeignPolicy.com, November 17, 2010. Accessed October 1, 2014. http://ricks.foreignpolicy.com/posts/2010/11/17/the_army_and_post_911_change.

Roberts, Clayton. The Logic of Historical Explanation University Park, PA: Pennsylvania State University Press, 1996.

Rostker, Bernard, Harry Thie, James Lacy, Jennifer Kawata, and Susanna Purnell. The Defense Officer Personnel Management Act of 1980: A Retrospective Assessment. Santa Monica, CA: RAND, 1993.

Rothbard, Murray N. “Gresham’s Law and Coinage.” Ludwig von Mises Institute. Accessed October 1, 2014. http://mises.org/money/3s5.asp.

Ryan, Alex J. “What is a Systems Approach?” Cornell University Library. September 10, 2008. Accessed October 1, 2014. http://arxiv.org/pdf/0809.1698.pdf.

Schein, Edgar H. Organizational Culture and Leadership. 2nd ed. San Francisco, CA: JosseyBass, 1992.

Schifferle, Peter J. “Anticipating Armageddon: The Leavenworth Schools and US Army Military Effectiveness, 1919-1945.” PhD diss., University of Kansas, 2002.

Schon, Donald A. The Reflective Practitioner: How Professionals Think in Action. New York, Basic Books, 1983.

Senge, Peter M. The Fifth Discipline: The Art and Practice of the Learning Organization. New York: Doubleday/Currency, 2006.

Skelton, William B. An American Profession of Arms: The American Officer Corps, 1784-1861. Lawrence, KS.: University Press of Kansas, 1992.

Skirbunt, Peter D. "Prologue to Reform: The 'Germanization' of the United States Army, 18651898.” PhD diss., The Ohio State University, 1983. 
Steele, Matthew F. “The Conduct of War.” Journal of the Military Service Institution of the United States 42, no. 151 (January-February 1908): 22-31.

Stein, Stephen K. “The Greely Relief Expedition and the New Navy.” International Journal of Naval History 5, no. 3 (December 2006). Accessed October 1, 2014. http://www.ijnhonline.org/wp-content/uploads/2012/01/Stein_-_pdf.pdf.

Stewart, Richard, ed. American Military History, Vol. 1, The United States Army and the Forging of a Nation, 1775-1917. Washington, DC: Center of Military History, US Army, 2005.

Swift, Eben. Remarks Introductory to the Course in Military Art, 1904. Fort Leavenworth, KS, 1904.

Tilghman, Andrew. "The Army’s Other Crisis: Why the Best and Brightest Young Officers are Leaving.” Washington Monthly. December 2007. Accessed October 1, 2014. http://www.washingtonmonthly.com/features/2007/0712.tilghman.html.

Tillson, John C. F. Reducing the Impact of Tempo. Alexandria, VA: Institute for Defense Analyses, 1999.

USA Today Editorial Board. “Update Military Academy Nominations: Our View.” USA Today. September 21, 2014. Accessed October 1, 2014. http://www.usatoday.com/story/opinion/2014/09/21/military-academy-educationcongress-nominations-editorials-debates/16015003/.

US Adjutant-General's Office. The Personnel System of the United States Army, Vol. 1, History of the Personnel System. Washington, DC, 1919.

US Army. Systems of Temporary Promotion for Officers. Analytical Study, United States Army Command and Staff College, June 24, 1946.

US Congress. House. To Increase the Efficiency of the Military Establishment of the United States: Hearing before the Committee on Military Affairs, 64th Cong., 1st sess., January 12, 1916.

US Congress. House. Universal Military Training: Statements Made by Maj. Gen Leonard Wood before the Senate Subcommittee on Military Affairs and the House Committee on Military Affairs, 64th Cong,, 1st sess., December 18, 1916 and January 31, 1917.

US Department of Defense. “Secretary of Defense Speech.” February 25, 2011. Accessed October 1, 2014. http://www.defense.gov/speeches/speech.aspx?speechid=1539.

Utley, Robert M. Cavalier in Buckskin: George Armstrong Custer and the Western Military Frontier, Rev. ed. Norman, OK: University of Oklahoma Press, 2001.

Vandergriff, Donald E. “Military Education - We Are Stuck in the Past.” Military.com: Military Opinions. January 13, 2005. Accessed October 1, 2014. http://www.military.com/Opinions/1,14790,Vandergriff_011305-P1,00.html. 
- The Path to Victory: America's Army and the Revolution in Human Affairs. Novato, CA: Presidio Press, 2002.

Wardynski, Casey, David S. Lyle, and Michael J. Colarusso. Towards a US Army Officer Strategy for Success: Employing Talent. Carlisle, PA: Strategic Studies Institute, May 2010.

Warner, Volney. General Officer Survey on Army Title X Activities. Washington, DC: Center for Army Analysis, 2011.

Webb, William J. "The Root Reforms and Army Schools and Branches.” Center for Military History Online. May 3, 2001. Accessed October 1, 2014. http://www.history.army.mil/documents/1901/Root-Schools.htm.

Weick, Karl E., Kathleen M. Sutcliffe, and David Obstfeld. “Organizing and the Process of Sensemaking.” Organization Science 16, no. 4 (July-August 2005): 409-421.

Weigley, Russell F. “The Elihu Root Reforms and the Progressive Era.” In Command and Commanders in Modern Warfare: Proceedings of the Second Military Symposium, US Air Force Academy, edited William Geffen. Washington, DC: Government Printing Office, 1969.

—. History of the United States Army. New York: Macmillan, 1967.

Wiebe, Robert. The Search for Order. New York: Hill and Wang, 1967.

Wiener, Frederick B. “Mex Rank Through the Ages.” Infantry Journal 54, (October 1943): 5764.

Wren, Gayden. A Most Ingenious Paradox: The Art of Gilbert and Sullivan. New York: Oxford University Press, 2001. 